ex Instituto Archaeologico Universitatis de Rolando Eötvös nominatae

C

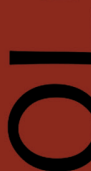

ப

$\varangle$

工

$\cup$

ه

$<$

in

ㄴ
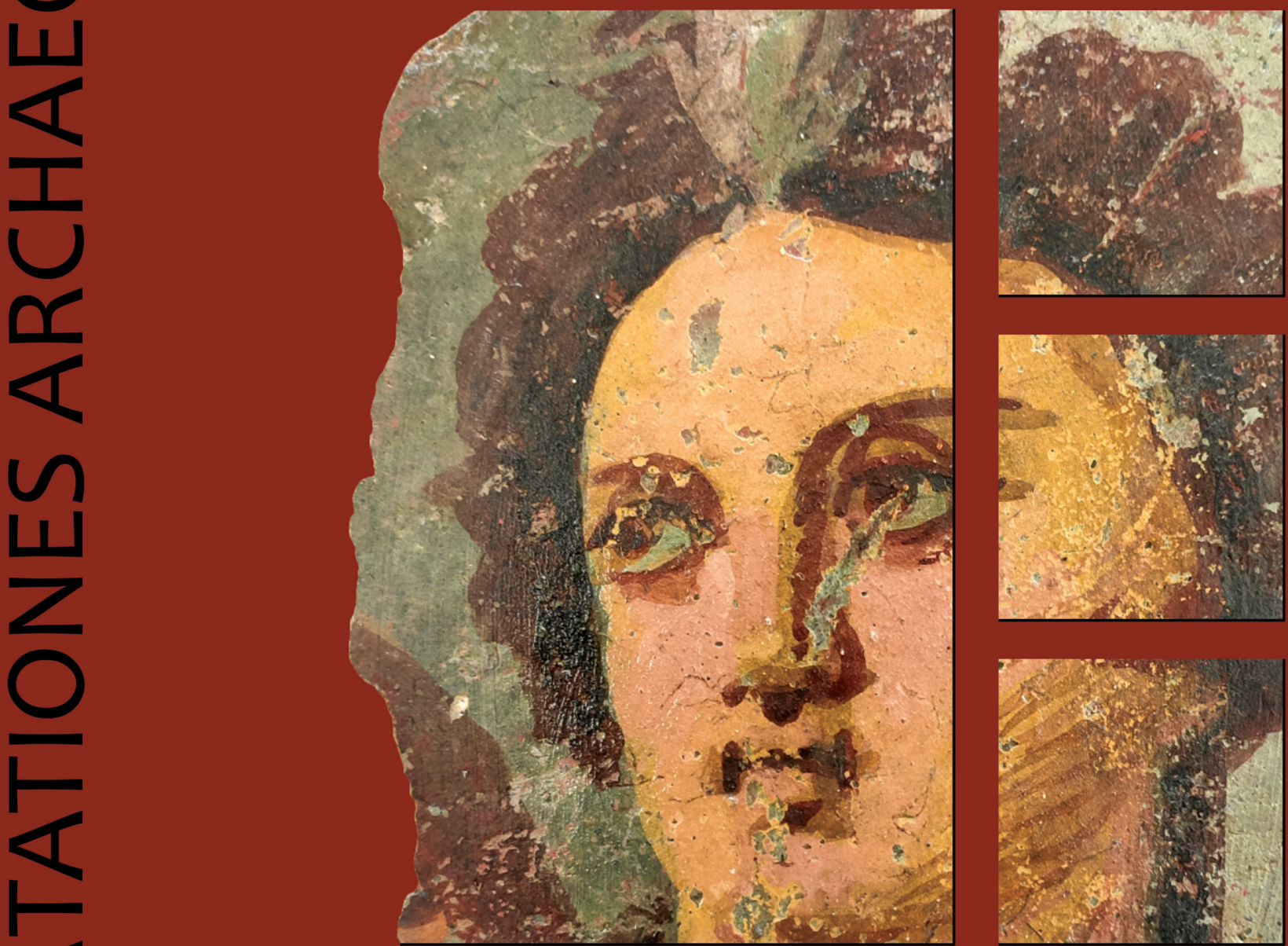

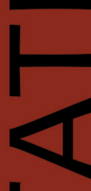

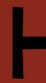

ח

Ш

un

n

0
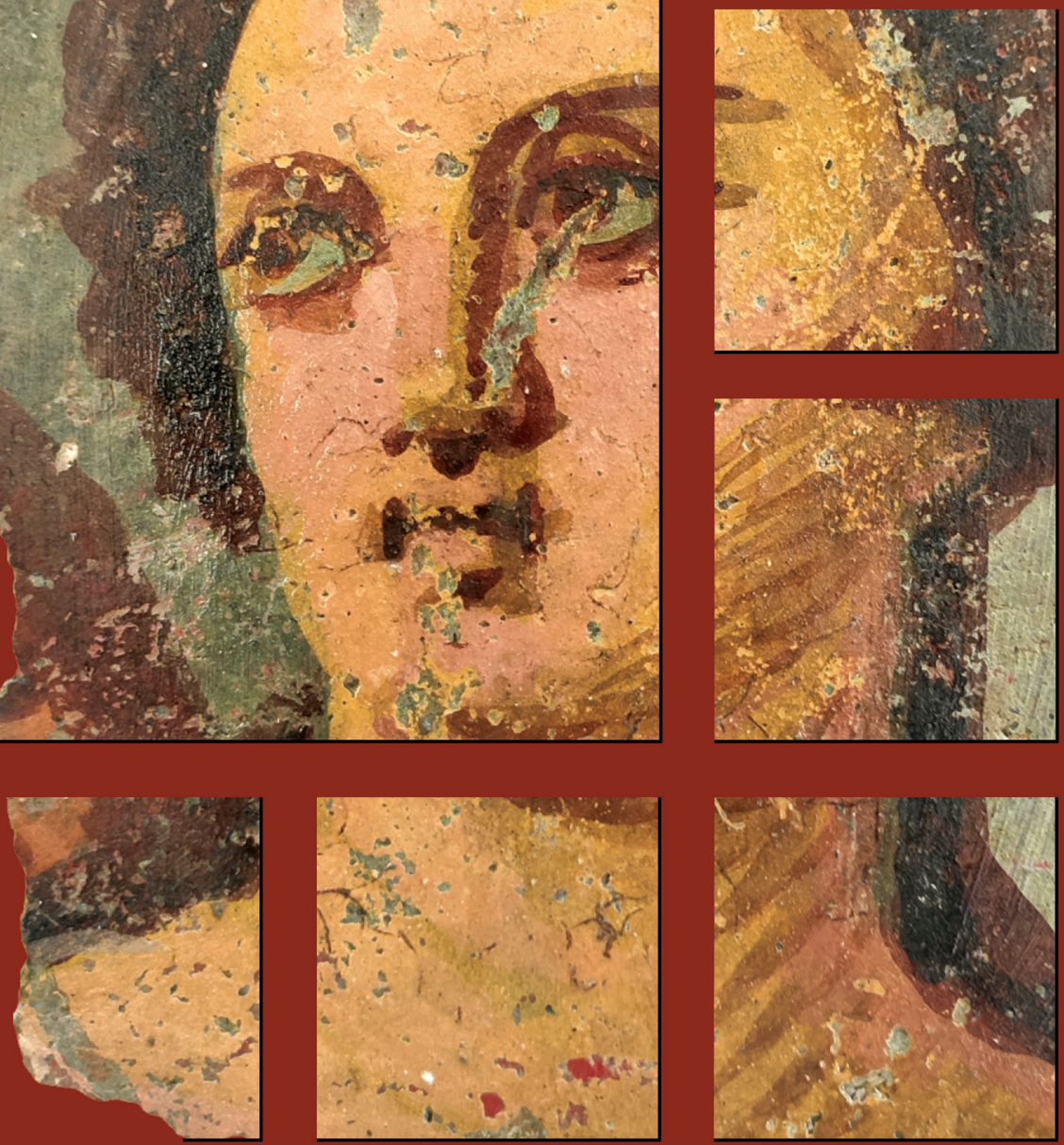

Serp 30 No. 8. 2020 


\section{Dissertationes Archaeologicae ex Instituto Archaeologico}

Universitatis de Rolando Eötvös nominatae Ser. 3. No. 8.

Budapest 2020 
Dissertationes Archaeologicae ex Instituto Archaeologico Universitatis de Rolando Eötvös nominatae Ser. 3. No. 8.

Editor-in-chief:

DÁvid Bartus

Editorial board:

LÁsZló BARTOSIEWICZ

LÁsZLÓ BORHY

ZOLTÁN CZAJLIK

IsTVÁN FELD

GÁBOR KALLA

PÁL RACZKY

MiKLÓS SZABÓ

Tivadar Vida

Technical editor:

Gábor VÁczi

Proofreading:

Szilvia BARTUS-SzÖLLŐsI

Zsófia KondÉ

Márton SZILÁGYI

Aviable online at http://ojs.elte.hu/dissarch

Contact: dissarch@btk.elte.hu

ISSN 2064-4574

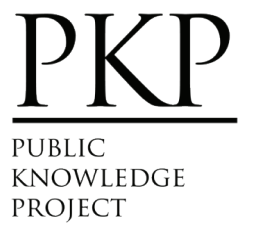

๑ ELTE Eötvös Loránd University, Institute of Archaeological Sciences

Layout and cover design: Gábor Váczi

Budapest 2020 


\section{CONTENTS}

\section{ARTICLES}

Maciej WAWRZCZAK - Zuzana KASENČÁKovÁ

Stará L'ubovña - Lesopark. Late Palaeolithic site and the problems associated with raw material mining

Attila PÉNTEK - Norbert FARAgó

Chipped stone assemblages from Schleswig-Holstein (North Germany) in the collection of the Institute of Archaeological Sciences - ELTE Eötvös Loránd University

Bence Soós 49

Middle Iron Age Cemetery from Alsónyék, Hungary

Tamás Szeniczey - Tamás Hajdu 107

Appendix - Results of the analysis of the Early Iron Age human remains unearthed at Alsónyék, Hungary

Lajos JuHÁsz - József Géza Kiss

Bound in bronze - a Roman bronze statuette of a barbarian prisoner

Csilla SÁRó

The fibula production of Brigetio: clay moulds

\section{Field Reports}

András Füzesi - Knut Rassmann - Eszter BÁnffy - Hajo Hoehler-Brockmann -

Gábor Kalla - Nóra Szabó - Márton SzIlágyi - Pál Raczky

Test excavation of the "pseudo-ditch" system of the Late Neolithic settlement complex at Öcsöd-Kováshalom on the Great Hungarian Plain

Gábor VÁczi - László RupNIK - Zoltán CZAJLIK - Gábor MEsterházy Bettina BitTner - Kristóf FÜlöP - Denisa M. LÖNHARdT - Nóra Szabó

The results of a non-destructive site exploration and a rescue excavation at the site of Pusztaszabolcs-Dohányos völgy északi part

Dávid BArtus - László Borhy - Szilvia JohÁczi - Emese SzÁmadó 181

Excavations in the legionary fortress of Brigetio in 2019 
Dávid BArtus - László Borhy - Emese SzÁmadó - Lajos Juhász - Bence Simon -

Ferenc Barna - Anita Benes - Szilvia Joháczi - Rita Olasz - Melinda Szabó

Excavations in Brigetio in 2020

\section{Thesis Abstracts}

Anett OszTÁs

The settlement history of Alsónyék-Bátaszék.

Complex analysis of its buildings in the context of the Lengyel culture

Csilla SzÁRAz

The region of the Zala and Mura Rivers (Zala County) in the Late Bronze Age.

Late Tumulus and Urnfield period

Ágnes KIRÁly

Human remains unearthed in settlement context from the Late Bronze Age -

Early Iron Age (Reinecke BD-HaB3) Northeastern Hungary

Gergely BóKA

Transformation of settlement history in the Körös Region in the period between the Late Bronze Age and the end of Iron Age

Gabriella G. DeLbó

Pottery production of the settlement complex of Brigetio

Adrienn Katalin BLAY

Die Beziehungen zwischen dem Karpatenbecken und dem Mediterraneum

von der II. Hälfte des 6. bis zum 8. Jahrhundert n. Chr. anhand Schmuckstücken

und Kleidungszubehör

Levente SAMU

293

Die mediterranen Kontakte des Karpatenbeckens in der Früh- und Mittel-

awarenzeit im Licht der Männerkleidung. Gürtelschnallen und Gürtelgarnituren

\section{REviEWS}

Gábor MESTERHÁZY

Czajlik, Z. - Črešnar, M. - Doneus, M. - Fera, M. - Hellmith Kramberger, A. Mele, M. (eds): Researching Archaelogical Landscapes Across Borders - Strategies,

Methods and Decisions for the 21th Century. Graz-Budapest, 2019. 


\title{
Test excavation of the "pseudo-ditch" system of the Late Neolithic settlement complex at Ocsöd-Kováshalom on the Great Hungarian Plain
}

Preliminary report

\author{
András FüZESI \\ Institute of Archaeological Sciences \\ ELTE Eötvös Loránd University \\ fuzesia@gmail.com
}

\section{Eszter BÁNFFY}

Deutsches Archäologisches Institut

Römisch-Germanische Komission

eszter.banffy@dainst.de

\section{Gábor KALLA}

Institute of Archaeological Sciences

ELTE Eötvös Loránd University

kalla.gabor@btk.elte.hu

\section{Márton SzILÁGYI}

Institute of Archaeological Sciences

ELTE Eötvös Loránd University

szilagyi.marton84@gmail.com
Knut RASSMANN

Deutsches Archäologisches Institut Römisch-Germanische Komission

knut.rassmann@dainst.de

Hajo HoeHLer-BrockmanN

Deutsches Archäologisches Institut Römisch-Germanische Komission

hajo.hoehler-brockmann@dainst.de

Nóra Szabó

Institute of Archaeological Sciences

ELTE Eötvös Loránd University

szabonori91@gmail.com

Pál RACZKY

Institute of Archaeological Sciences ELTE Eötvös Loránd University raczky.pal@gmail.com

\begin{abstract}
In 2018, the RGK's research team led by Knut Rassmann undertook the magnetometer survey of the Late Neolithic site of Öcsöd-Kováshalom over a roughly 65 ha large area. An enclosure system of three concentric semi-circular ditches was detected around the tell-like mound that formed the core of the settlement. In order to resolve these issues, we organised a small field school excavation with the support of the RGK and with the participation of the archaeology students of the ELTE Institute of Archaeological Sciences between July 13 and 25, 2020. We opened an $8 \times 2 \mathrm{~m}$ trial trench across the north-eastern part of the innermost ditch appearing on the magnetogram. We uncovered a ditch segment with a V-shaped cross-section, a width of $315 \mathrm{~cm}$ and a depth of $295 \mathrm{~cm}$. We recovered a total of 17,430 finds with a weight of $194.4 \mathrm{~kg}$ (pottery sherds, daub, animal bones, bone tools, chipped and polished stone implements, quern stones, mussels, and ochre). In our preliminary report, we made a reconstruction of infilling process based on the quantitative distribution of the finds (frequency and weight data) and the different characteristics of the fill layers.
\end{abstract}

Between 1980 and 1987, the Institute of Archaeological Sciences of the Eötvös Loránd Univer- 
sity (ELTE) organised field schools at the Late Neolithic settlement complex of Öcsöd-Kováshalom, in the heartland of the Hungarian Plain. As a result of these excavations, the main traits of the site's occupation patterns could be outlined. First four, then seven single-layer settlement units were identified around the central core of the settlement covering almost 21 hectares on the northern bank of a former meandering channel of the River Körös. ${ }^{1}$ The settlement units consisted of closed groups of houses that were separated by smaller unoccupied areas. This spatial configuration, representing a complex settlement variant reflecting a specific form of integration, was identified for the first time in the Tiszazug micro-region. At Öcsöd, the central occupation area appeared to be very similar to the lowermost, initial layers of tell sites in the region. However, this settlement was abandoned before growing to a real tell mound.The associated single-layer settlement units around it existed and were occupied simultaneously during the Late Neolithic. ${ }^{2}$ It soon became clear that Ócsöd itself was also surrounded by a loose cluster of small single-layer settlements in the Tiszazug micro-region. ${ }^{3}$ A similarly complex settlement system has been identified among the Late Neolithic settlements of the Körös region. ${ }^{4}$ All things considered, a settlement concentration and a roughly simultaneous process of nucleation was hypothesised for the Late Neolithic in the area along the River Tisza. Moreover, the formation of tells was observed in the centre of more dense settlement areas in the southern Hungarian Plain. ${ }^{5}$ Thus, the regional settlement patterns in the Tisza distribution appeared to be even more complex: tells were the norm as settlement centres in the southern Hungarian Plain, while only single-layer sites occur north of the River Körös. ${ }^{6}$

The stratigraphic observations made during the excavation of the central tell-like settlement at Öcsöd indicated two successive developmental phases of the Tisza culture, each with a distinctive material culture (Tisza I and Tisza II) in the broader Tisza region. ${ }^{7}$ A cluster of aboveground houses with timber-framed walls was identified on the central settlement mound of Òcsöd-Kováshalom. This spatial unit was surrounded by a zone of pits, while crouched inhumation burials, associated to some extent with these pits, lay east and west of the houses. ${ }^{8}$ The settlement's central part was bounded by a rectangular fence system open towards the former waterfront: the rectangular modules of the houses were in this sense incorporated into a larger rectangular architectural space on this central mound. ${ }^{9}$

The observations made during the excavation of the tell-like mound at Öcsöd indicated that the houses, pits, and burials were integrated into units by feature types in this spatial system and that these units hark back to the spatially discrete house-pit-grave modules of the Alföld Linear Pottery Culture (ALPC), which underwent a reconfiguration, leading to the emergence of new norms in the spatial organisation of the settlement, which was undoubtedly linked to the changes in the social dimension. ${ }^{10}$ The novel expressions of social identity

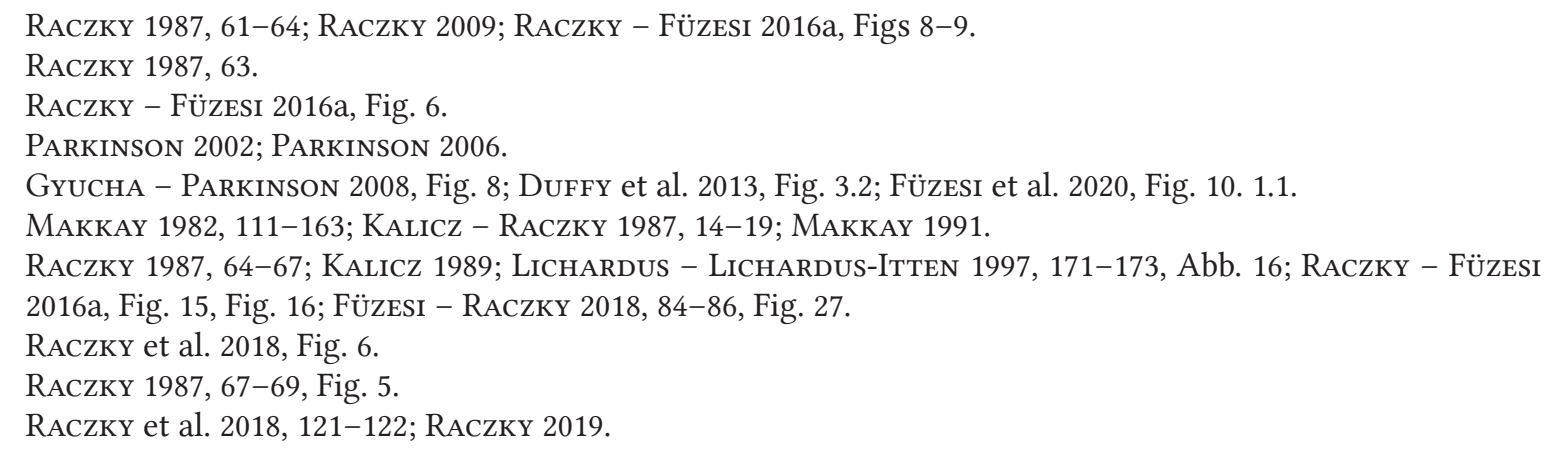




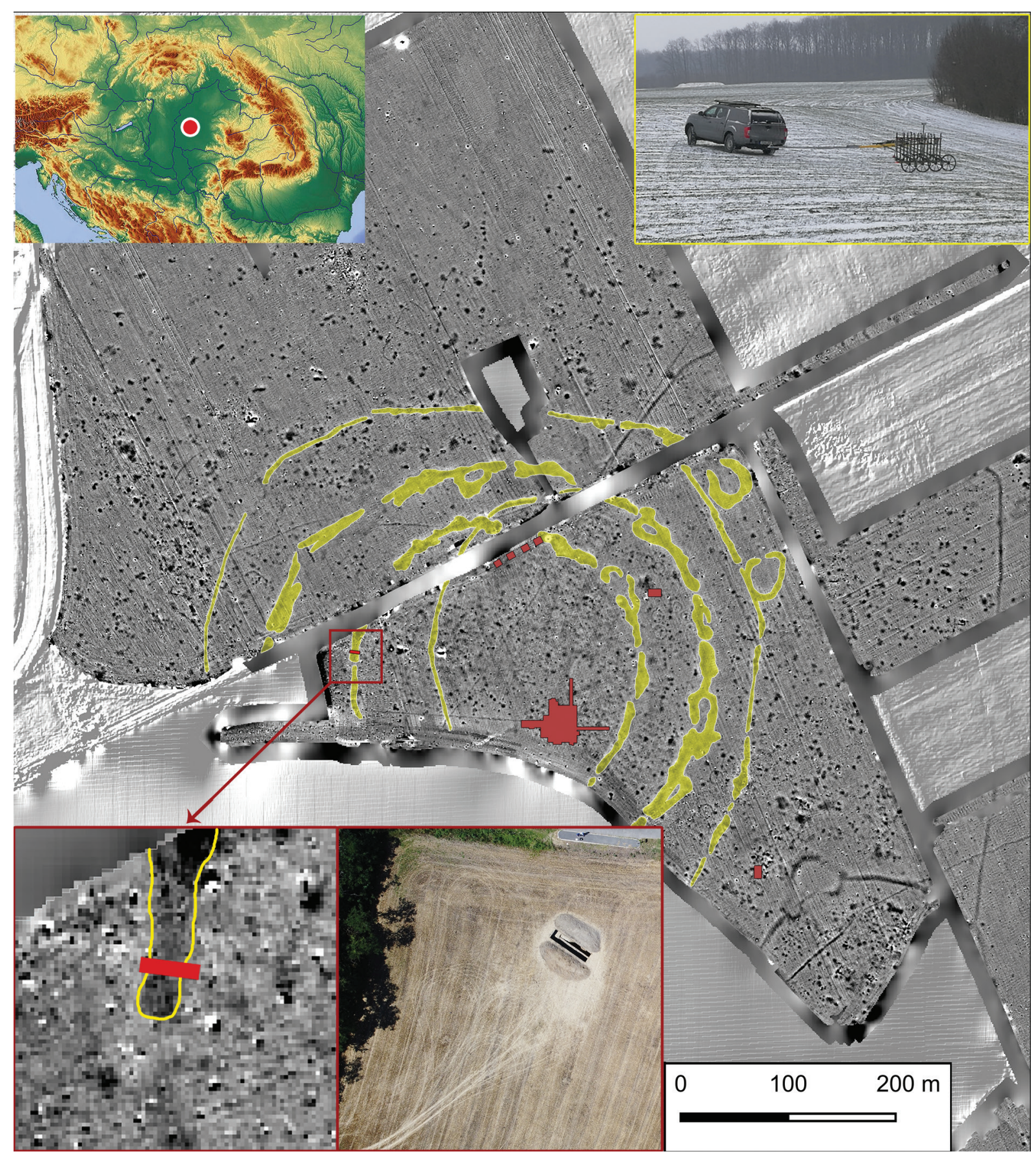

Fig. 1. Result of the magnetometer survey carried out by RGK research team in 2018 at the Late Neolithic site of Öcsöd-Kováshalom (elements of the triple ditch system highlighted in yellow). Based on the survey results, a $2 \times 8 \mathrm{~m}$ trench was excavated (marked in red) as a continuation of previous excavations $(1983-1988,2006)$. The trench (highlighted image) was opened across the western segment of the innermost ditch.

are reflected, for example, by contracting females on the left side and males on the right side in the mortuary domain. ${ }^{11}$

Together with the research results of four other tell and tell-like settlements in the Tisza region (Hódmezővásárhely-Gorzsa, Szegvár-Tűzköves, Vészto-Mágor, and Berettyóújfalu-Herpály),

11 SiKLÓsI 2013, 140-151. 


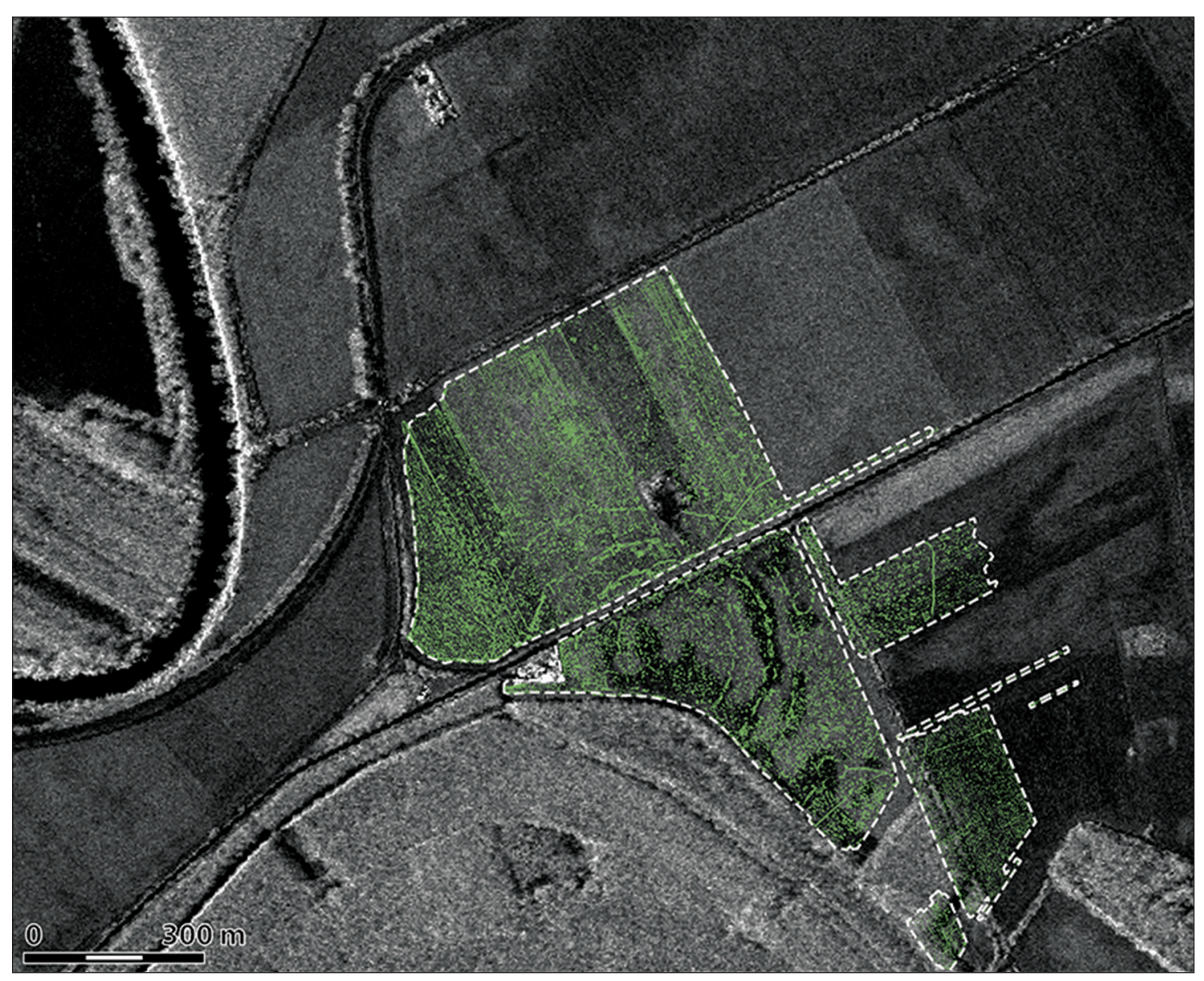

Fig. 2. Ȯcsöd-Kováshalom. X-SAR satellite image taken on 8/2/2019 (DLR) using microradar waves. The image shows the archaeological features in the Late Neolithic settlement area.

the finds and findings of the excavations at Öcsöd were presented for the first time to the international archaeological community as part of an exhibition and the accompanying catalogue in 1990 in Frankfurt am Main, organised by the Museum für Vor- und Frühgeschichte. ${ }^{12}$ This event, in the wake of the fall of the Berlin Wall, was a symbolic occasion for the presenting Hungarian prehistoric research. At this time, Neolithic settlement mounds, as "prominent" features, and the archaeological phenomena observed in their context were believed to encapsulate the focal issues of the Late Neolithic in the eastern Carpathian Basin. Similarly to the tells of the Tisza region, the Vinča and Karanovo tells served as anchors for the relative chronology of the South-East European Neolithic as well as for the dynamics of everyday life. Although the dating of the Tisza-Herpály-Csőszhalom cultural complex was shifted to the earlier 5th millennium BC after the necessary adjustments to the calibrated radiocarbon-based chronology in the early $1980 \mathrm{~s}^{13}$ an insistence on the "traditional archaeological chronology", according to which the final period of the Neolithic should be dated between 2800 and $2500 \mathrm{BC}$, continued to persist. ${ }^{14}$ In fact, the first absolute chronological system of the Late Neolithic tells

12 MeIER-ARENDt 1990.

13 Sherratt 1983, Fig. 6.

14 МАКкAY 1982, Chronological chart. 
of the Tisza region based on calibrated radiocarbon data was constructed at a rather late date, in the 1990s. ${ }^{15}$ In this new chronological model, the 14 radiocarbon measurements from Öcsöd indicated that the occupation of the settlement could be placed between 5110 and 4831 (68.3\%) cal BC, around the turn of the 6th millennium BC.

In 2018-2019, the Römisch-Germanische Kommission (RGK) of the German Archaeological Institute in Frankfurt am Main and the ELTE Institute of Archaeological Sciences (Budapest) launched a joint research project, "Neolithic tells and their landscape along the Tisza River between 5000 and 4500 BC", with the goal of revisiting the archaeological analyses and interpretations of the 1990s within the framework of a modern analytical and interpretative approach in line with the current standards of European archaeological scholarship. As a first step, the RGK's research team led by Knut Rassmann undertook the magnetometer survey of the Late Neolithic site of Öcsöd-Kováshalom over a roughly 65 ha large area (Figs 1-2). The multi-disciplinary studies placed the previous image of the late Neolithic settlement into an entirely new perspective.

First, it became apparent that the former settlement was much more extensive than the previously calculated 21 ha: its size was determined to be 45.5 ha based on the magnetometric data. ${ }^{16}$ However, the greatest surprise was that an enclosure system of three concentric semi-circular - now infilled - ditches with a radius of almost $250 \mathrm{~m}, 200 \mathrm{~m}$, and $125 \mathrm{~m}$, respectively, was detected around the tell-like mound that formed the core of the settlement. ${ }^{17}$ Furthermore, several smaller gaps were noted in the ditches, which make this structure one of the easternmost occurrences of an enclosure variant, the so-called pseudo-ditch construction in Europe. ${ }^{18}$ This in itself raised the question of the functional and chronological relationship between the ditch system and the Late Neolithic settlement, and called for the identification of other formal traits of the ditches.

In order to resolve these issues, we organised a small field school excavation with the support of the RGK and with the participation of the archaeology students of the ELTE Institute of Archaeological Sciences, led by Pál Raczky, Gábor Kalla and András Füzesi between July 13 and 25, 2020 (Fig. 13-15). We opened an $8 \times 2 \mathrm{~m}$ trial trench across the north-eastern part of the innermost ditch appearing on the magnetogram (Fig. 1). At a depth of $160 \mathrm{~cm}$, we uncovered a ditch segment with a V-shaped cross-section, a width of $315 \mathrm{~cm}$ and a depth of $295 \mathrm{~cm}$ (measured from the modern surface; Fig. 3). We found an unusual deposit made up of pottery sherds, bone fragments, and lithics between 60 and $90 \mathrm{~cm}$ in the fill overlying the ditch (Fig. 5). This deposit would suggest that both the construction of the ditch and its backfilling was probably accompanied by ritual activity. The initial examination of the find material from the ditch revealed that it was dominated by finds bearing the distinctive traits of the early and classical Tisza culture (Tisza I-II). The eastern edge of the ditch was cut by a beehive-shaped pit containing mainly classical Tisza (Tisza II) ceramics.

These general observations strongly suggest that the recently discovered ditched enclosure and its use-life at Öcsöd-Kováshalom coincide with the occupation of the Late Neolithic set-

15 Hertelendi - Horváth 1992; Hertelendi et al. 1995; Hertelendi et al. 1998; Summarised chronological table: PArkinson 2006, Fig. 4.4.

16 FÜZESI et al. 2020.

17 FÜZESI et al. 2020, Fig. 10. 3.1.

18 LEFRANC et al. 2017. 


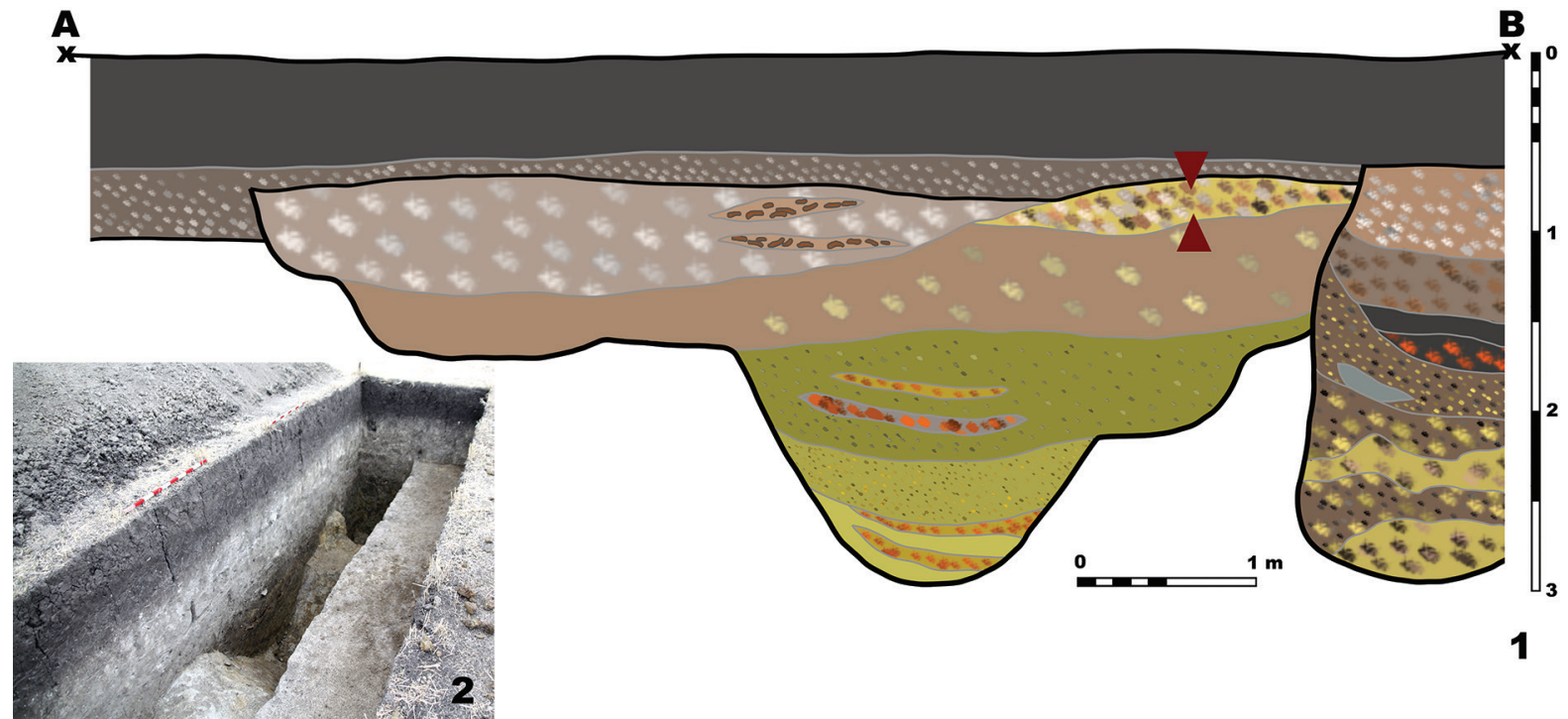

Fig. 3. Section drawing (1) and photograph (2) of the excavated trench. The strongly saline subhumus was followed by a layer rich in archaeological finds, in which a continuous find concentration (location marked by red triangles) indicated the extent of deposition activities. Under this artificial infill, the clayey, greyish-yellow layers in the ditch's lower third are the result of natural infilling. A storage pit, also dating from the Late Neolithic, cuts the ditch: the pit's layers reflect a similar infilling process as in the ditch's upper part.

tlement. Their co-occurrence can be interpreted as an indication that while the inner clusters of the Neolithic settlement were arranged around a centre rising prominently above its surroundings in the visual sphere, the smaller ditch segments also displayed the same central geometric arrangement in the invisible sphere. Moreover, the tell-like central place apparently connected the two concentric systems, and in this sense, the above-ground and below-ground features at Öcsöd formed a single "centripetal spatial unit", as well as a single complex central reference system for the community. ${ }^{19}$ In sum, the arrangement of the archaeological features suggests two dimensions of a "situated process" and their local meshing.

The 2020 test excavation and the results of the earlier corings have raised a spate of new questions regarding the intrasite spatial dynamics of the Öcsöd settlement, which we can hopefully clarify with further targeted excavations in the future.

\section{Preliminary evaluation of the Öcsöd find material}

The $2 \times 8 \mathrm{~m}$ trench cutting across the innermost ditch of the triple ditch system discovered on the Late Neolithic settlement of Ócsöd, we proceeded to excavate totally with hand tools. During the spadework, we strove to employ the smallest excavation and documentation units, so that we would be able to reconstruct the process of how the ditch was infilled. We worked with arbitrary excavation levels of $20 \mathrm{~cm}$ intervals, although in practice, this could only be approximated due to the differences in the compactness of each fill layer. The statistical bias in the scatter of finds was corrected by measuring each excavation level with a total station. In each level, the finds were kept separate per square meter. During the excavation, 150 such 
excavation units were defined in 15 levels (Fig. 4.1). We excavated the entire trench down to a depth of $1.5 \mathrm{~m}$; after determining the size and position of the ditch segment, only the northernmost $1 \mathrm{~m}$ strip was excavated further due to lack of time. We used the data from this northern section for the analysis presented here for an appropriate statistical comparison. ${ }^{20}$

We recovered a total of 17,430 finds with a weight of $194.4 \mathrm{~kg}$ (pottery sherds, daub, animal bones, bone tools, chipped and polished stone implements, quern stones, mussels, and ochre),
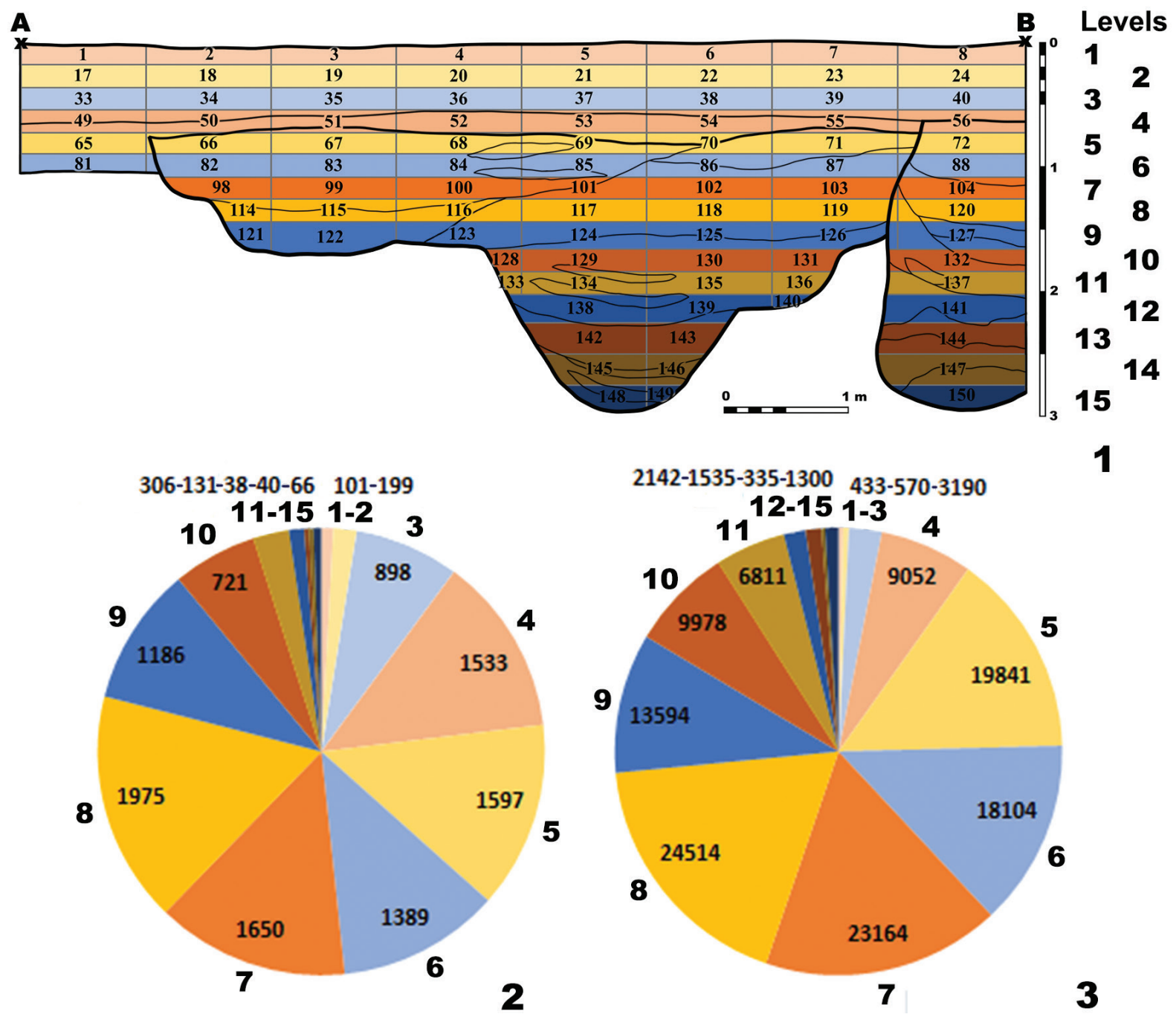

1

Fig. 4. We distinguished 150 excavation units in 15 levels at every $20 \mathrm{~cm}$ (1). A total of 17,430 finds with a total weight of $194.4 \mathrm{~kg}$ were recovered. Based on the frequency (2) and weight distribution (3) of the recovered sample, the find concentration was the greatest between 0.5-1.2 m. In levels 1-4, disturbed by modern cultivation, fragmentation was more pronounced. (The diagrams show the data for the northern squares of the excavation trench.)

of which 11,830 fragments $(134.5 \mathrm{~kg})$ are included in the preliminary statistical evaluation. The distribution of finds by piece (Fig. 4.2) and weight (Fig. 4.3) indicate more intense fragmentation in levels 1-4 affected by modern cultivation. Even in the case of the three most common find types, the average fragment size is rather small (3-4 $\mathrm{g}$ for pottery, $1-2 \mathrm{~g}$ for daub, and 1-3 $\mathrm{g}$

20 In Table 1, the levels that were excavated for the full width of $2 \mathrm{~m}$ (levels 1-7) consist of two rows of excavation units in each level. Units from the northern row are marked with "A", while the units of the southern row, which were not part of this analysis, are marked with "B." 


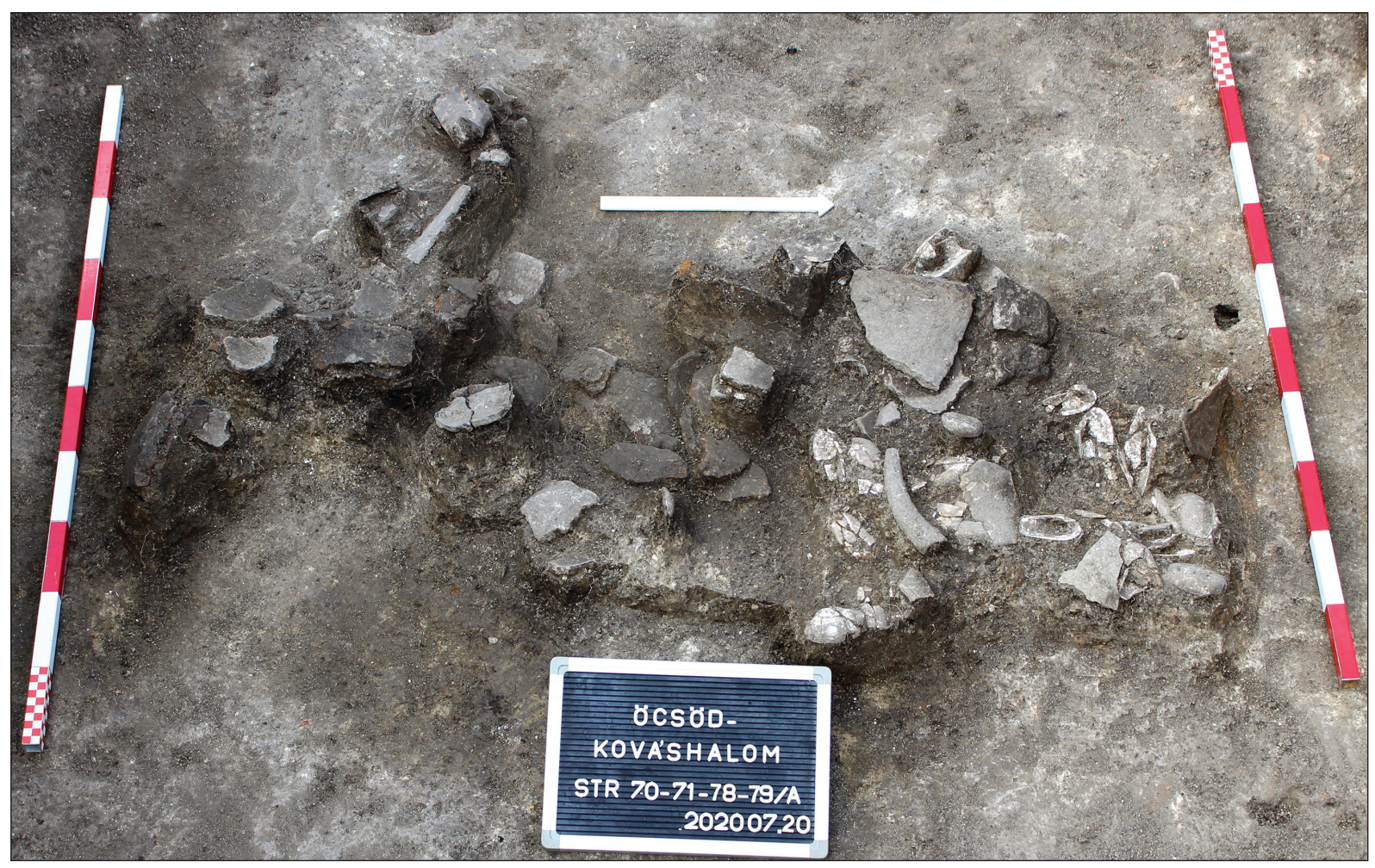

Fig. 5. Photo of the find concentration found in the upper part of the ditch, during excavation.

for animal bones), which doubled in level 4. Most of the finds were recovered from between 0.5-1.2 $\mathrm{m}$ in the entire excavated section. Already at this depth, a feature with a distinct fill (Pit 1) could be identified in the trench's north-eastern corner. The frequency of finds per level decreased rapidly after level 8, and from level 11 downward, we found a scant amount of finds, similarly as in the upper levels disturbed by cultivation. However, these finds were much larger. The average weight of the pottery fragments ranged between 15-20 g, the daub pieces weighed between 25-35 g on average, with extreme values of 3 and $55 \mathrm{~g}$. The animal bone fragments followed a similar pattern: in addition to an average of $20-40 \mathrm{~g}$, fragments weighing 5 and $100 \mathrm{~g}$ also occurred. These data are higher than the mean values of the middle levels rich in finds (pottery fragments: $14 \mathrm{~g}$, daub: $17 \mathrm{~g}$, animal bone: $11 \mathrm{~g}$ ).

Looking at the breakdown of all finds according to the features identified from the infill levels, the major differences between the layer disturbed by cultivation (henceforth: humus or subhumus), the ditch, and the storage pit can be correlated with the excavation method by levels. The differences in the distribution of finds according to quantity (Fig. 6.1) and weight (Fig. 6.2) between the identified archaeological features (Fig. 6.3) vary in the case of the different units. The humus/subhumus layer, which contains a significant number of finds (36.67\%), declined sharply in terms of weight $(24.62 \%)$. The ditch's upper section, which underlay the subhumus layer, was divided into two parts based on the different nature of its fill (Fig. 3.1). The eastern part was mixed with clay patches of different colours, while the western part seemed homogeneous in the lower part and mixed, although to a lesser extent, with limestone patches in its upper part. The direction of these layers indicate that the infilling took place from the eastern side, i.e. from the inner side of the ditch. The same number of finds could be assigned to both parts, which accounted for $47.03 \%$ of all finds by quantity and for $53.43 \%$ by weight. The lower third of the ditch fill was relatively poor in finds, with about $10 \mathrm{~kg}(7.81 \%)$ and 740 

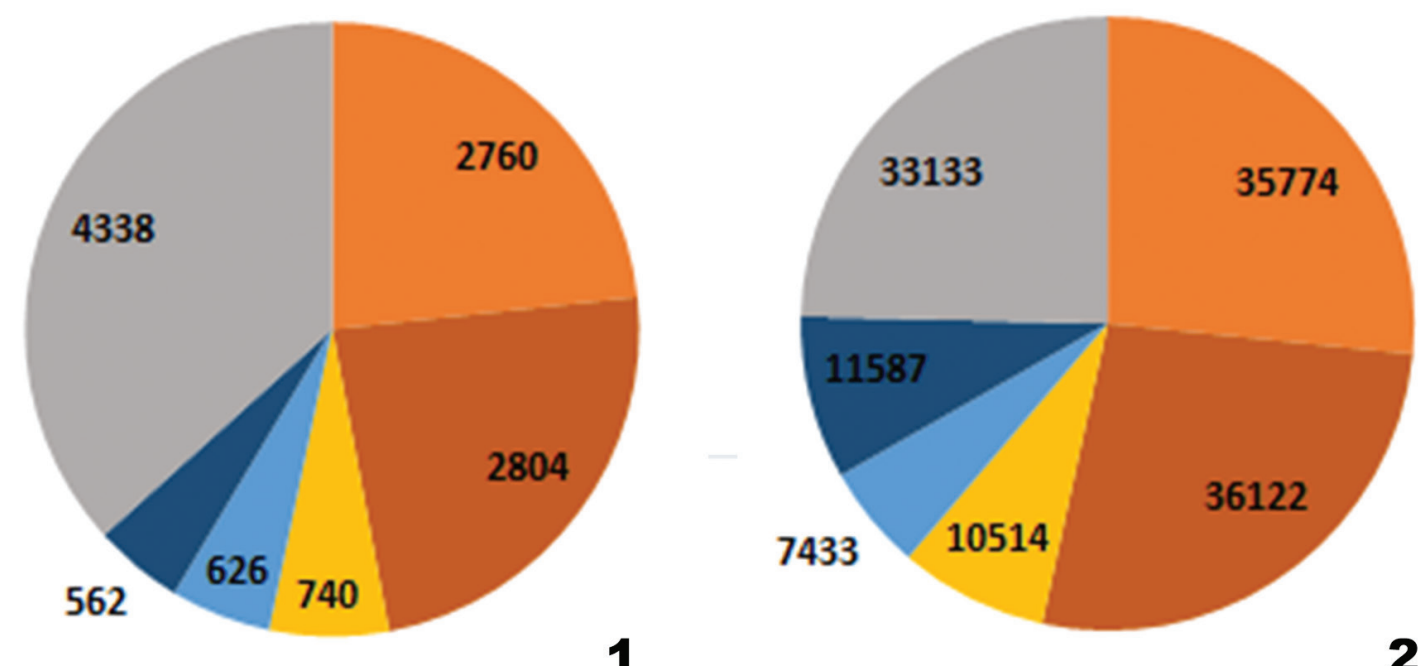

1

2
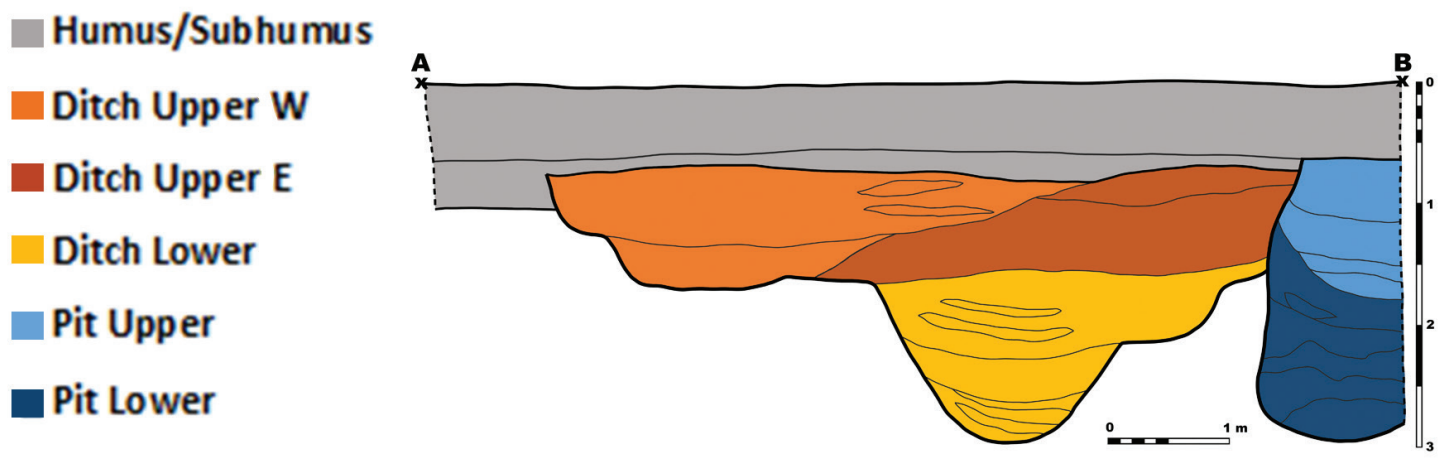

3

Fig. 6. Quantitative distribution of the finds (1 - by frequency, 2 - by weight) based on the excavated and identified archaeological features (3). Underlying the humus-subhumus layer disturbed by modern cultivation (grey) was an intensive infilling of the ditch's upper part (orange-red). Based on the different nature of the fill, we divided it into two parts. The orientation of the layers indicated that the infilling proceeded from the eastern side, i.e. from the inner side of the ditch. The ditch's lower third was relatively poor in finds (yellow). The infilling of the storage pit (light and dark blue) can also be divided into two parts: the upper layers mixed with ash and charcoal were richer in finds, while the lower clayey part contained fewer finds.

pieces (6.26\%). The large pit cutting the ditch was also divided into two parts based on the documented changes in its fill. The upper part was dominated by ashy layers with charcoal, while the lower layers were made up of humus mixed with yellow clay. Based on the figures, their nearly identical number of finds (626 and 562) differed substantially in terms of their weight (7.4 and $11.6 \mathrm{~kg}$ ). This is because much larger pottery fragments were found in the lower part compared to the more fragmented material in the upper part.

The finds comprise a large number of pottery fragments (cf. Fig. 7 for a selection of the finds) bearing both the curvilinear-spiral patterns of the early Tisza I style (Fig. 7.5) and the textile patterns of the Tisza II style of the site's late occupation horizon (Fig. 7.7). The gradual transformation of the two styles can be traced in the material from the settlement's stratified part. ${ }^{21}$ The perhaps most magnificent example of the classical Tisza textile pattern was found on the floor of pit that cut the ditch, i.e. was stratigraphically later. This find type (6082 fragments 

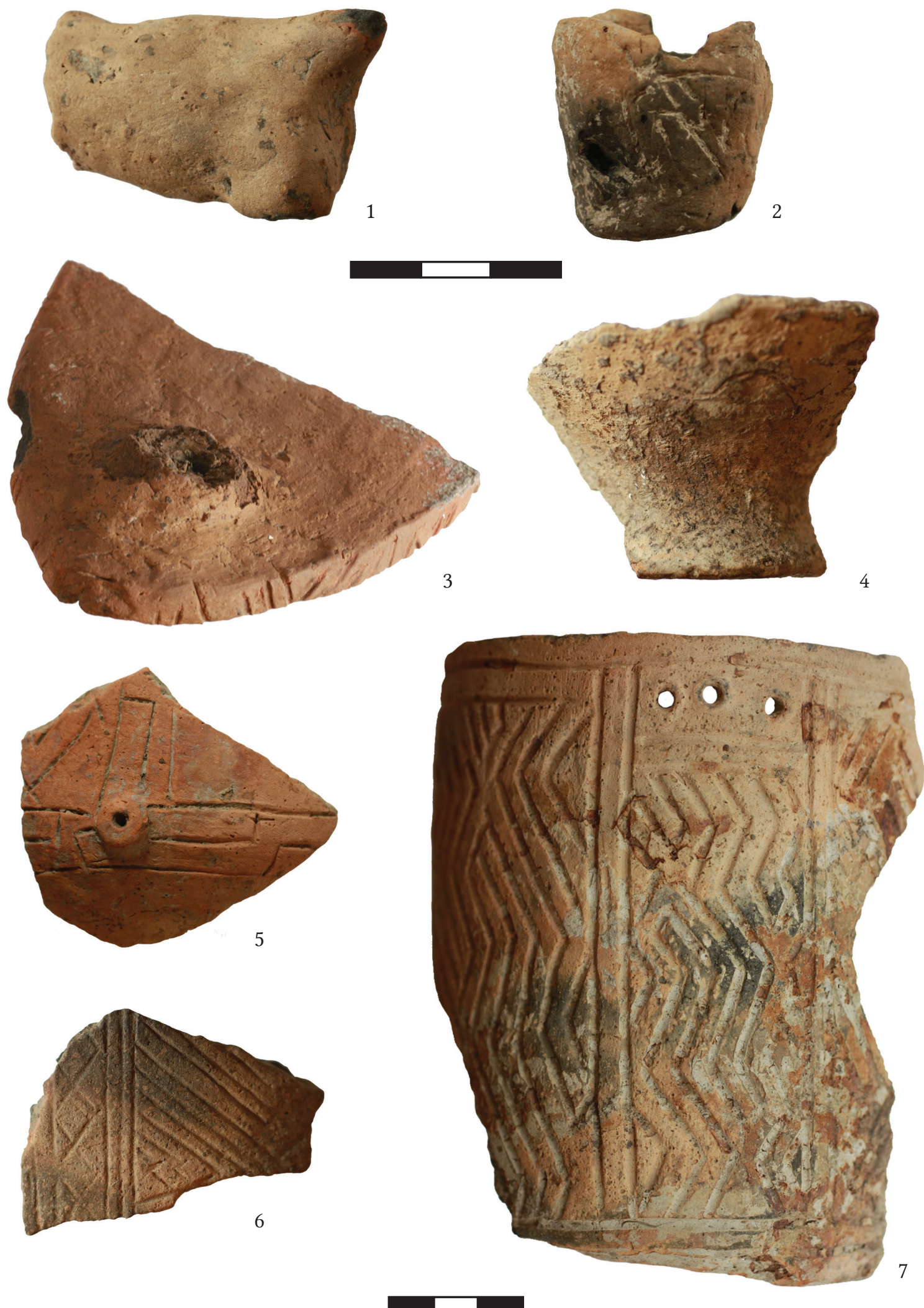

Fig. 7. Selection of the ceramic material of the ditch segment excavated at Öcsöd-Kováshalom. 1 - fragment of a zoomorphic figurine, 2 - miniature vessel, 3 - fragment of an unusual artefact set on legs (possibly a vessel) (photographed from below), 4 - fragment of an undecorated pedestalled vessel, 5 - biconical vessel with Tisza I decoration, 6 - fragment of a vessel bearing textile decoration, 7 - fragment of a cylindrical vessel with Tisza II decoration from the floor of the storage pit. 

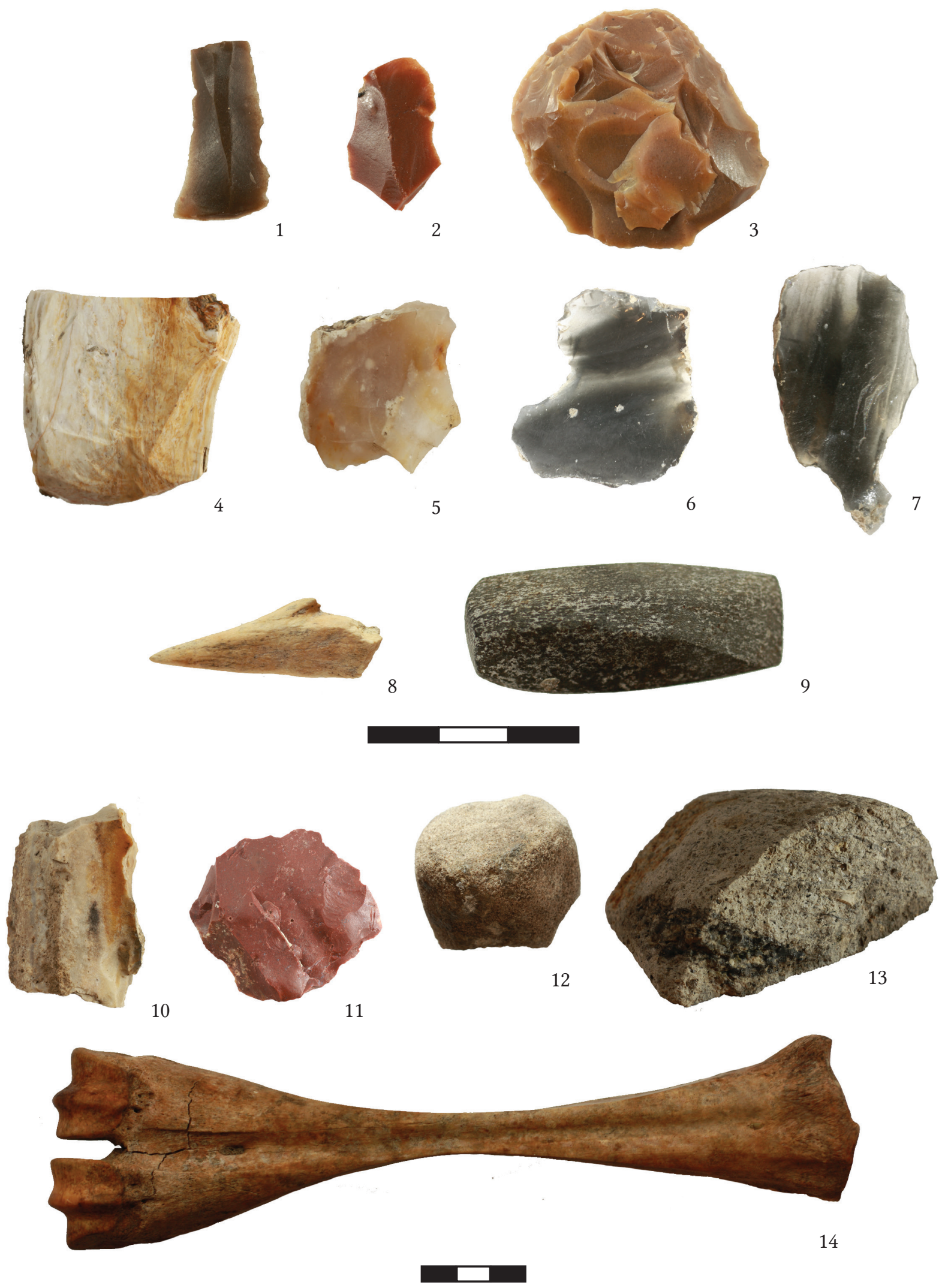

Fig. 8. Selection of the stone implements and bone tools from the ditch segment excavated at Öcsöd-Kováshalom. 1-7, 10, 11 - chipped stone implements, 8 - fragment of a bone harpoon, 9 - small polished stone axe, 12 - burnisher, 13 - quern stone fragment, 14 - bone tool. 
weighing $76.6 \mathrm{~kg}$ in the northern section) is the most prominent, conforming to the general composition of Neolithic materials.

The animal bone sample is strongly fragmented, and thus a different-than-average correlation can be noted between its quantity (3124 pieces) and weight (39.4 kg). Only in level 13 did we find larger bones, which, despite their small number, had a greater total weight (Fig. 9.1-2). In the quantitative sequence, daub was the third artefact type, represented by 555 pieces weighing $9 \mathrm{~kg}$.

The lithic material was made up of 337 chipped implements weighing $2.4 \mathrm{~kg}$ (Fig. 8.1-7,10-11). The fragmentation of the polished stone tools, of which only one was intact (Fig. 8.9), is illustrated by the fact that the weight of the seven artefacts totalled no more than $329 \mathrm{~g}$. In the case of quern stones, representing a much larger type (Fig. 9.13-14), the 11 fragments weighed 1.2 $\mathrm{kg}$. Bone tools (Fig. 9.8,14) were represented by 20 artefacts $(688 \mathrm{~g})$.

One of the recurring elements of Neolithic assemblages is the large number of mussel shells, which occasionally form layers, or occur together with human remains, sometimes in contexts with a symbolic-ritual aspect. ${ }^{22}$ We collected a heavily fragmented material, in which intact shells are rare, in the excavated area. In this sense, their number (1555) is not representative, even if their total weight of almost $4 \mathrm{~kg}$ can be said to be significant.

Ochre is a popular and special pigment in the Neolithic, which can be found not only in its used state, but also as raw material lumps in settlement features and graves. ${ }^{23}$ Compared to the quantity found in the previously excavated areas, mainly in the multi-layer part of the settlement ( 446 pieces, $3.7 \mathrm{~kg}$ ), the $2 \times 8 \mathrm{~m}$ large trench contained a large amount of ochre. The highly fragmented assemblage (139 pieces) weighed $778 \mathrm{~g}$. The distribution between the two ochre varieties, yellow and red, shows a minor divergence from the trend in the material from previous excavations, in which red ochre accounted for only one-third of the fragments. The 64 red ochre finds of 2020 represented almost one-half of the recovered fragments. Yellow ochre lumps were also found in the subsoil during the excavation of the lower part of the storage pit. A lump of red ochre was embedded in a large daub fragment. The naturally yellow material turns red under the effect of heat, i.e. the unburnt ochre lump in the clay used for construction turned red when the building burnt down. These data from Öcsöd would suggest that the pigments were probably procured from relatively nearby sources.

The infilling of the excavated ditch segment and the pit cutting it was examined based on find type distributions per excavation units. ${ }^{24}$ We examined the data from 92 units broken down into the following categories: pottery sherds, daub, animal bones, bone tools, chipped and polished stone implements, quern stones, mussel shells, and ochre (Figs 10-12). In the case of find types whose fragmentation was more pronounced or fragmentation possibly continued during excavation and storage, the weight data were used. In contrast, the number of pieces was considered authoritative for bone and stone tools. The categories were determined according to the Jenks Natural Breaks Classification.

Pottery fragments were present in almost all excavation units, but the two largest concentra-

22 Pavúk 1994, 96, Abb. 39; Raczky 2012, 97, Fig. 1.

23 Siklósi 2013, 149-150; Whittle et al. 2013, 75, Fig. 3.20.

24 Cf. Domboróczki - RAczky 2010, 208-209, Fig. 5, for a similar spatial analysis with the goal of reconstructing the infilling processes of the features excavated at the Körös culture site of Ibrány-Nagyerdő. 

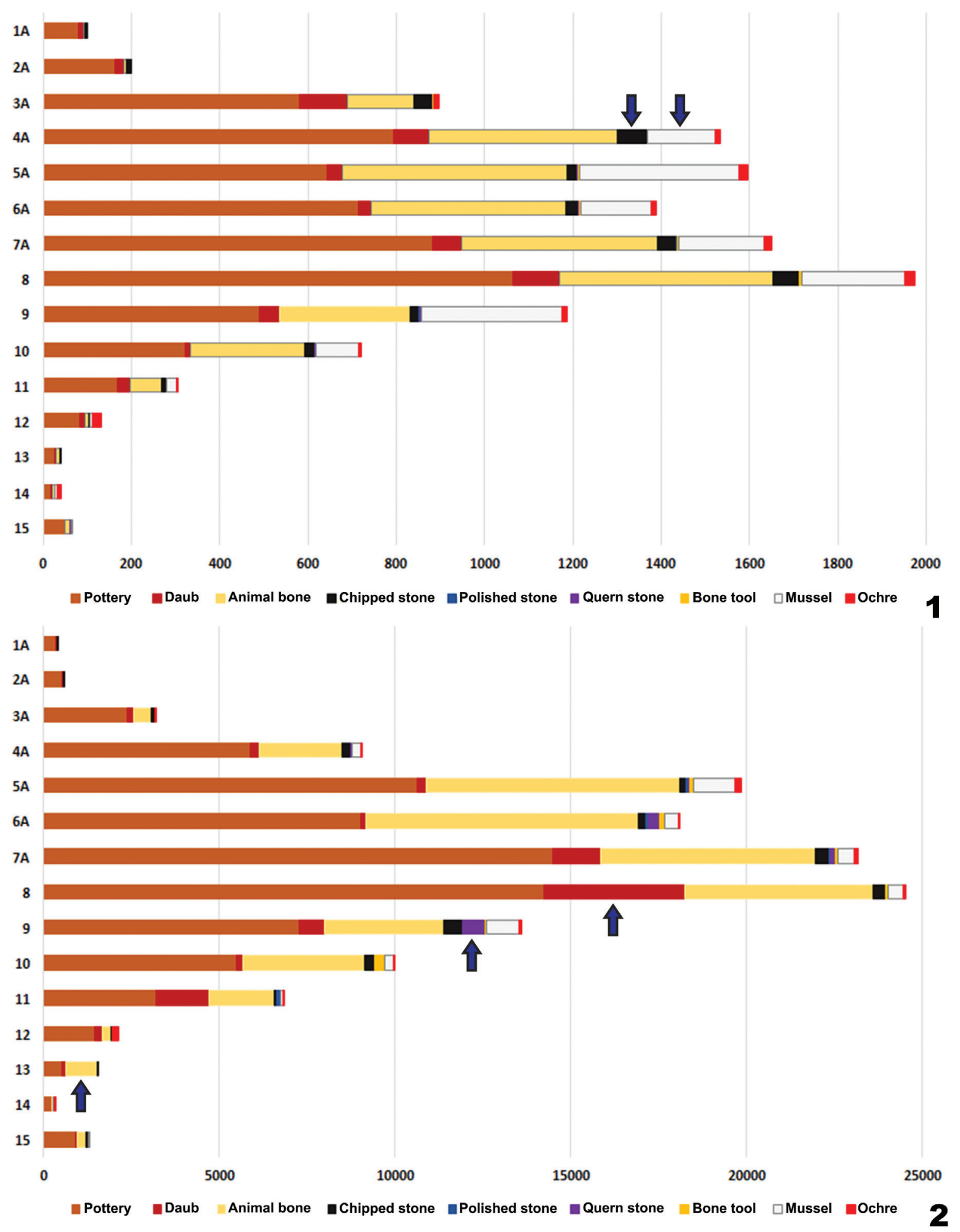

Fig. 9. Distribution of different find types by level ( 1 - by frequency, 2 - by weight). The increase in the number of finds is continuous down to level 8 (150 cm depth), followed by an abrupt decline (level 11, $2 \mathrm{~m}$ depth), after which the number of pieces and their weight remained minimal $(<100$ pieces, $<2 \mathrm{~kg})$. Except for levels 1-4 under the ploughzone, the correlation between frequency and weight data is relatively even, with the most spectacular differences between the two data sets indicated by blue arrows. Chipped stone implements and molluscs found in greater numbers from level 4 downward represent a moderate weight compared to their number. A positive weight differences could be seen in the case of the daub fragments found in level 8 , the quern stones found in level 9, and the relatively large animal bone fragments found in level 13. 

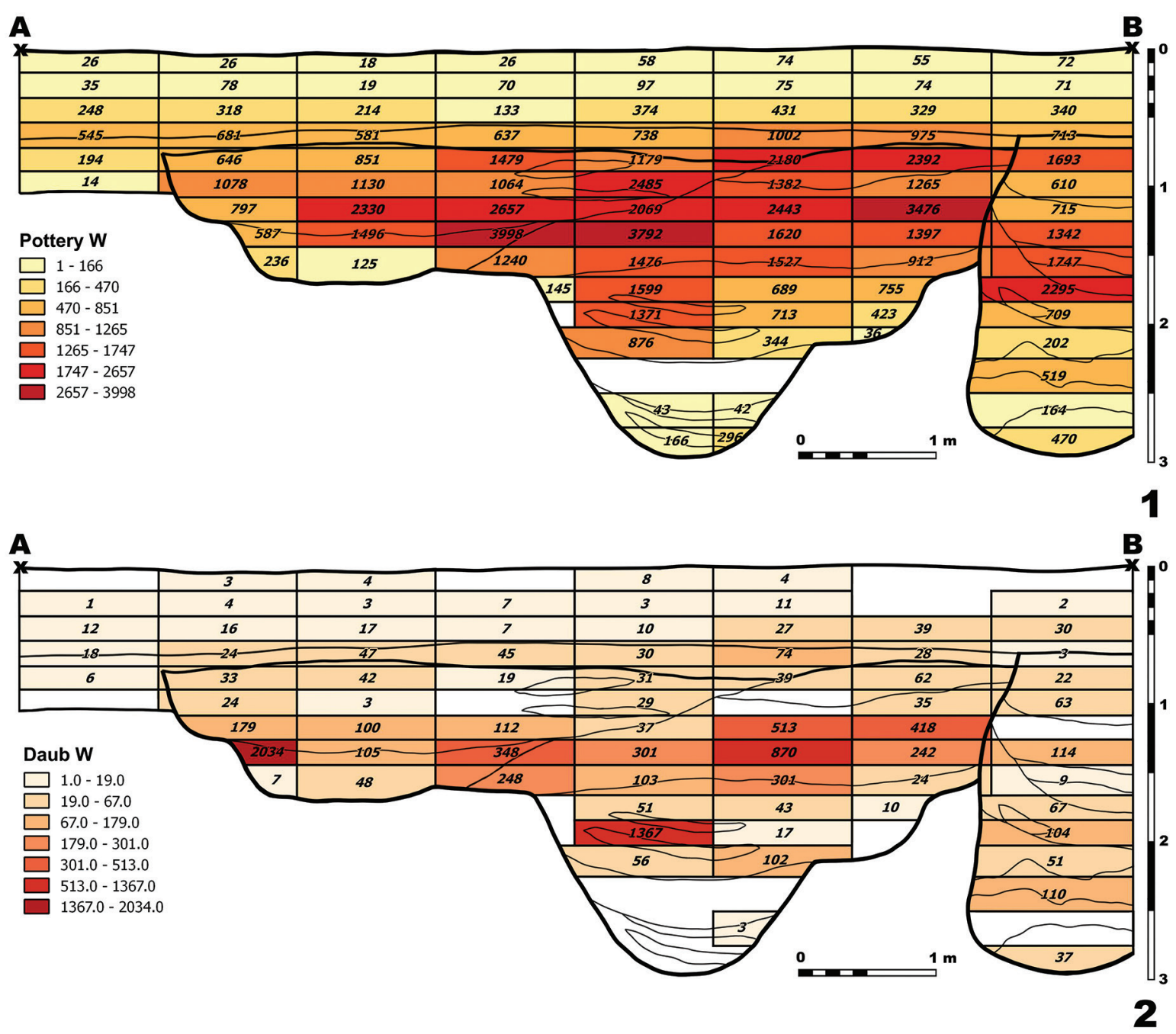

Fig. 10. Spatial distribution of pottery sherds (1) and daub fragments (2) by excavation units. The weight data are given in grams, categories were determined according to the Jenks Natural Breaks Classification.

tions were documented between levels 5-9, in the upper part of the ditch, and level 10 of the storage pit (Fig. 10.1). Daub was found in over $80 \%$ of the units, although its occurrence showed greater concentrations than that of pottery (Fig. 10.2). The three largest categories were noted in the ditch, in levels 7 and 8 . The highest concentration was identified by the western edge of the ditch, across a width of 130-150 cm, where large chunks of daub were mixed with the fragments of a large storage jar. An accumulation of daub was noted in a relatively closed layer in the ditch's lower part, which is documented in the section drawing (Fig. 3.1).

The accumulation of animal bones shows a similar pattern to that of pottery (Fig. 11.1). Except for three occasions, the 20 bone tools were each found singly in the excavation units: three from the subhumus, thirteen from the upper part of the ditch, four from the upper part of the storage pit. Moving from right to left, the location of the bone tools in the ditch (Fig. 11.1) is increasingly deeper, again suggesting an infilling from the right, i.e. the eastern side.

The chipped stone implements appeared in most of the examined units, except for the lower part of the ditch (Fig. 11.2). However, their proportion in the storage pit is negligible compared to the other find types. The two largest categories were identified in three levels in the ditch. The middle level corresponds to the accumulation pattern of pottery sherds and animal bones, 


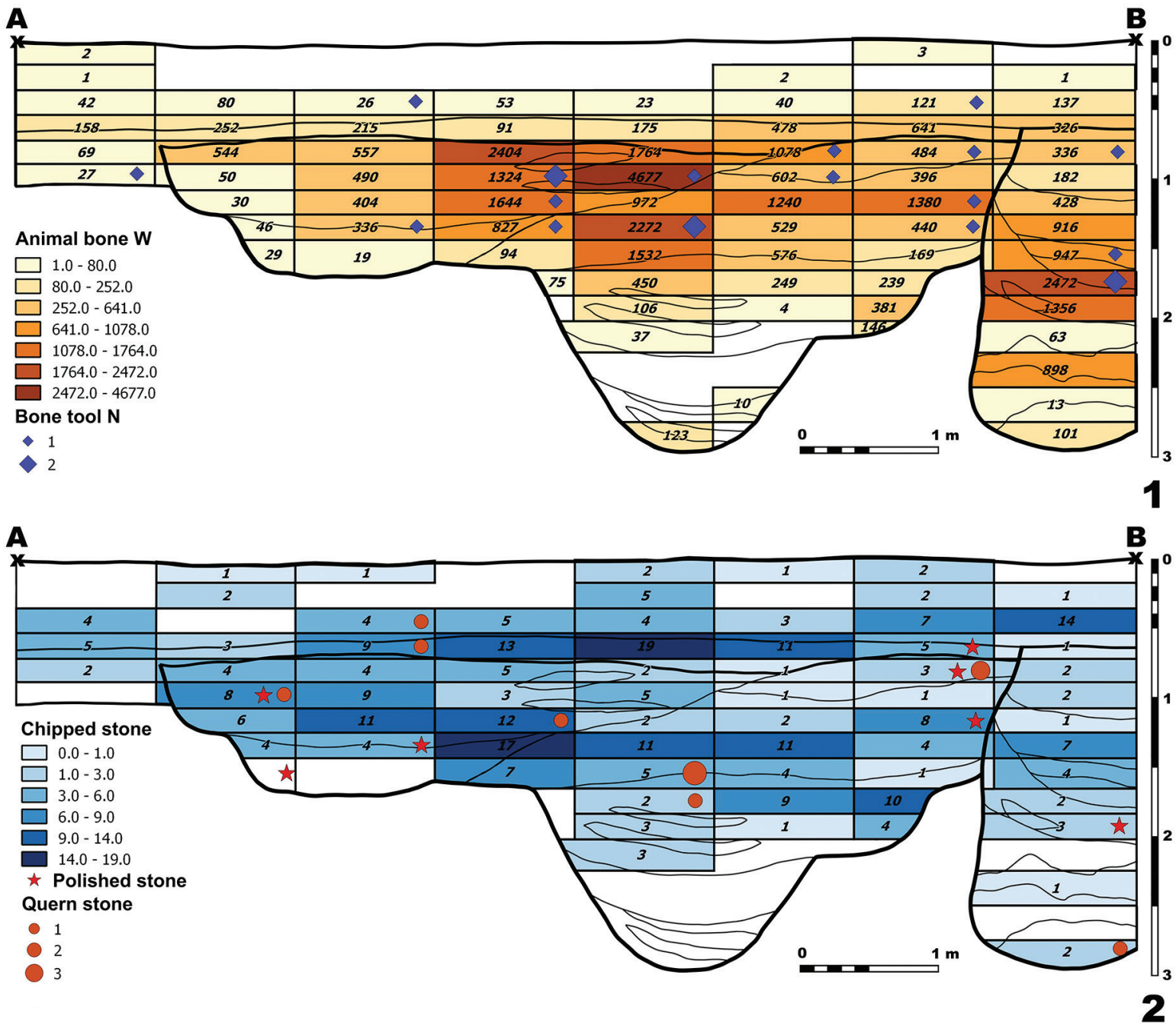

Fig. 11. Spatial distribution of animal bones (1) and stone tools (2) by excavation units. The weight data of animal bones and chipped stone implements are given in grams, the categories were determined according to the Jenks Natural Breaks Classification. The bone tools, polished stone tools, and quern stones are represented by their frequency (number of pieces).

the other two were associated with the final levels of two deposition units. The amount of lithics $(21 \mathrm{~g})$ in the level closing the fill of the ditch's lower part is significant only in comparison to the other find types that are virtually lacking from this unit. Most chipped stone implements were found at the boundary of the subhumus and the upper part of the ditch, in level 4. Of the polished stone tools, one piece was found in the subhumus, five in the upper part of the ditch, and one at the bottom of the storage pit's upper fill. The spatial distribution of the stone implements found in the ditch is similar to that of bone tools. Of the quern stone fragments, two were found in the subhumus, seven in the upper part of the ditch, one in the lower part, and one on the floor of the storage pit. Due to their modest number, their data only complements the conclusions that can be drawn from the patterning of the other find types.

The weight distribution of mussel shells conforms to the scatter of the pottery sherds and animal bones (Fig. 12.1). Due to their smaller quantity, their accumulation pattern is more conspicuous. Ochre occurred in one-half of the excavation units: larger quantities were noted in the eastern half of the ditch's upper part and in the pit cutting it from the east (Fig. 12.2). 

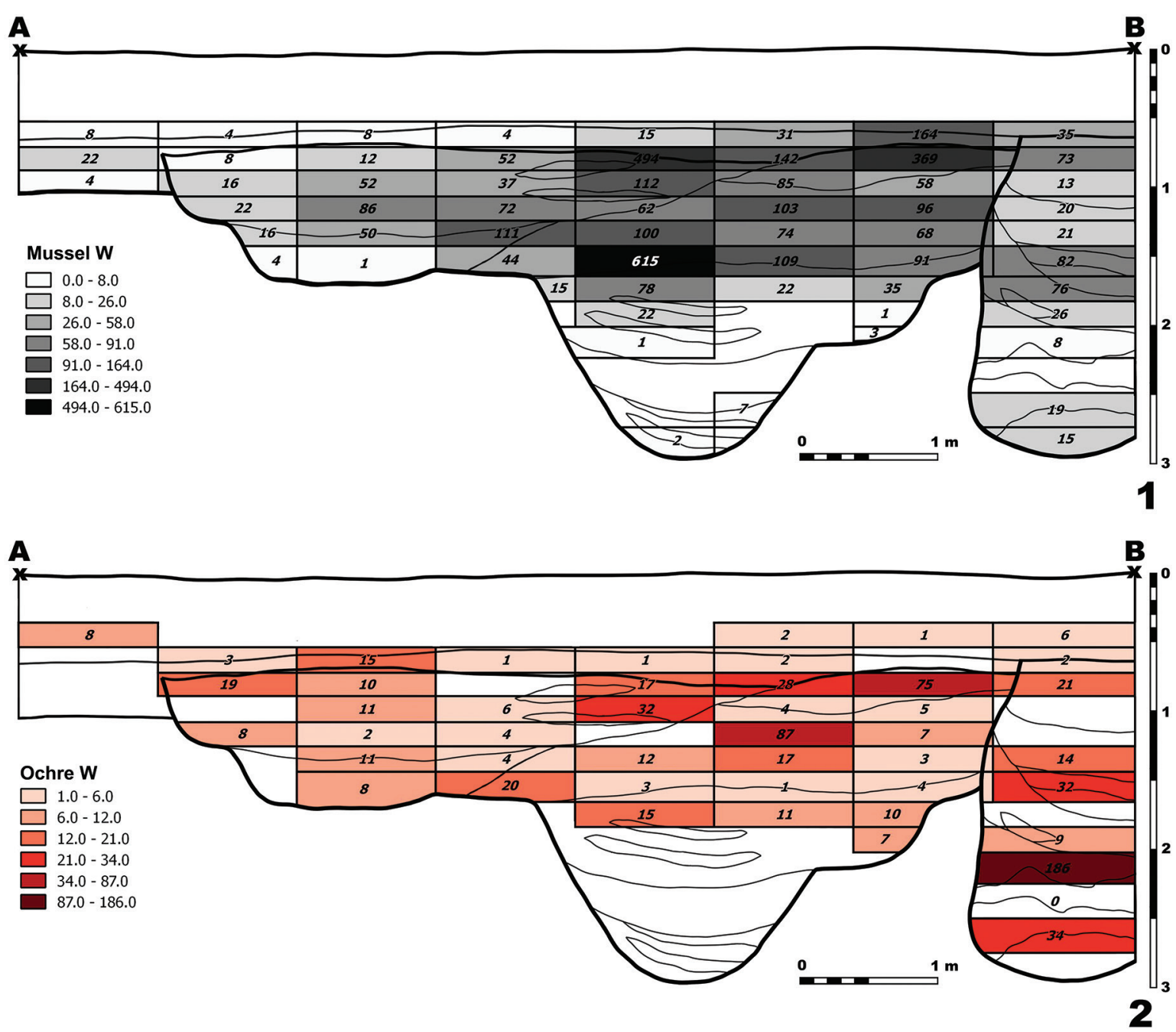

Fig. 12. Spatial distribution of mussels (1) and ochre fragments (2) by excavation units. The weight data are given in grams, the categories were determined according to the Jenks Natural Breaks Classification.

This raw material was strongly overrepresented compared to the other find types in the latter feature, with the highest concentration in the pit's lower part, where other finds were rare.

We distinguished five depositional units within the two partially excavated features (Fig. 6.3), based on the quantitative distribution of the finds (Fig. 4) and the different characteristics of the fill layers (Fig. 3.1). The frequency (Fig. 4.2) and weight data (Fig. 4.3) of these interpretive categories were supplemented with the distribution of the different find types (Fig. 9.1-2). The evaluation of the find types by excavation units (Figs 10-12) provided a more detailed understanding of the infilling processes. Based on this multi-level analysis, we can reconstruct the process as follows:

- The lower part of the investigated ditch segment has alternating grey and yellow clayey layers poor in finds, reflecting an intermittently recurring natural infilling, the single exceptions being the finds accumulated in levels 10-12 in the ditch's western half, especially the concentration of daub. These spatially discrete accumulations possibly represent two separate infilling events, which partially interrupted the natural infilling of the ditch. 
- The latter process was succeeded by the intensive infilling of the ditch's upper part, which was performed on several occasions of currently unknown durations. Among the finds from the levels overlying the depth of $1.5 \mathrm{~m}$, the distribution of the more frequent types (pottery sherds, animal bone, daub, chipped stone implements) confirms the repetitive nature of the infilling. The layers with distinct find concentrations suggest two to three such major events. The distribution of the less frequent find types (bone and stone tools) complement this with information about the spatial dimensions of the infilling. The find locations indicate an infilling process starting from the east, from the inner side of the ditch system. The extent of this activity is illustrated by the continuous find concentration uncovered below the strongly saline subhumus (Fig. 5, on Fig. 3.1 the section drawing, the location of the concentration is marked with red triangles).

- The layer sequence of the pit cutting the ditch segment, also dating from the Late Neolithic, indicates an infilling process resembling the ditch's upper part. The pit's upper part, which contained a larger number of finds, was characterised by fill levels with ash and charcoal testifying to a closer association with human activity. In contrast, the levels mixed with yellow clay containing a smaller number of finds layers in its lower part reflect a decrease in anthropogenic effects and a more pronounced natural infilling process. We thus witness the termination of two man-made features that lost their original function as a result of natural processes and their infilling with settlement debris.

The spatial distribution of the finds indicated large-scale levelling activities on the central tell-like part of the settlement excavated in the 1980s. ${ }^{25}$ This deliberate spatial reorganisation played an important role in the life of the community and it was probably also accentuated in their symbolic communication, at least judging from a structured deposit and related phenomena. ${ }^{26}$ The infilling of the ditch segment excavated in 2020 can be considered as having been a similarly deliberate act. Due to the small size of the excavated area, we have not

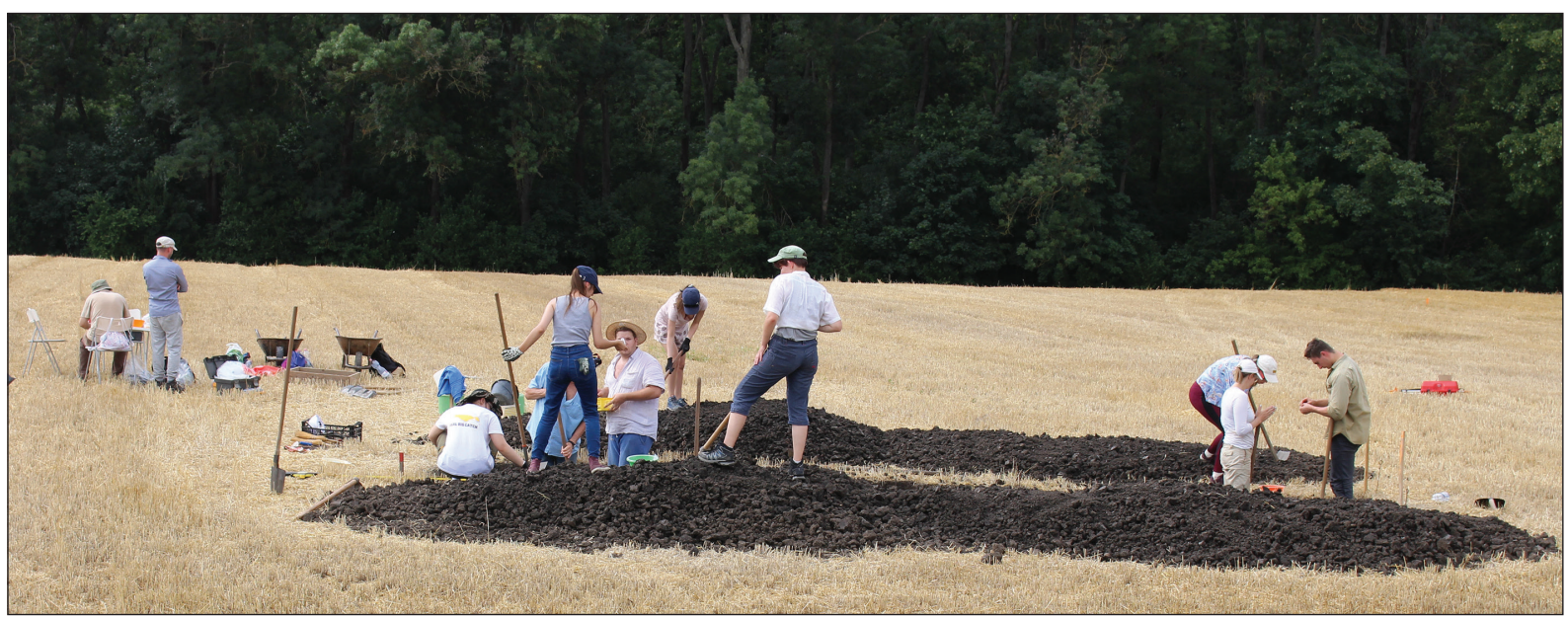

Fig. 13. The planned excavation of the $2 \times 8 \mathrm{~m}$ trench cutting the Late Neolithic ditch system at Ócsöd-Kováshalom was undertaken as a field school for students at the ELTE Institute of Archaeological Sciences.

25 FÜZESI-RACZKY 2018, 49-52.

26 RACZKY-FÜZESI 2016b; RACZKY et al. 2018, 124-130. 
yet found any evidence of a possible symbolic act associated with the termination of the ditch system. The stratigraphic position of the pit, which fortunately fell into the excavated ditch segment, proved that life continued in certain parts of the Late Neolithic settlement of Öcsöd-Kováshalom after the infilling of the inner ditch of the enclosure. One intriguing issue that remains to be answered is the relation between the abandonment of certain settlement parts and the final infilling of the pseudo-ditch system, alongside the clarification of the local events that led to the final abandonment of this Late Neolithic environment.

\section{Acknowledgement}

The Öcsöd project was funded by the National Cultural Fund of Hungary (NKA Grant K-135073).

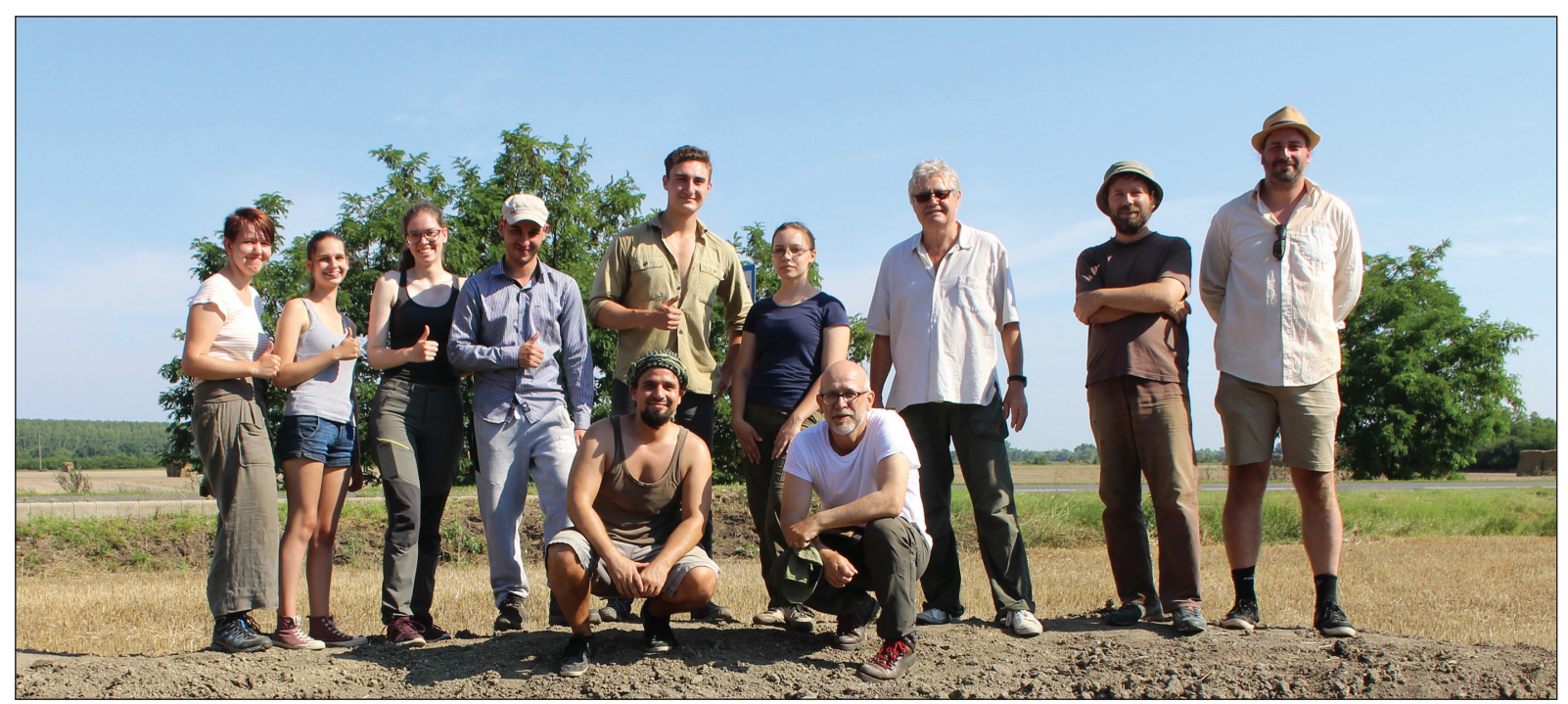

Fig. 14. Öcsöd-Kováshalom, the excavation team of the 2020 season: first row - Attila Király, Gábor Kalla; second row - Kamilla Kersánszki, Maja Kolbe, Dorottya Réka Láng, Bertalan Pillik, Ákos Kutyifa, Zsófia Csüllög, Pál Raczky, András Füzesi, Márton Szilágyi.

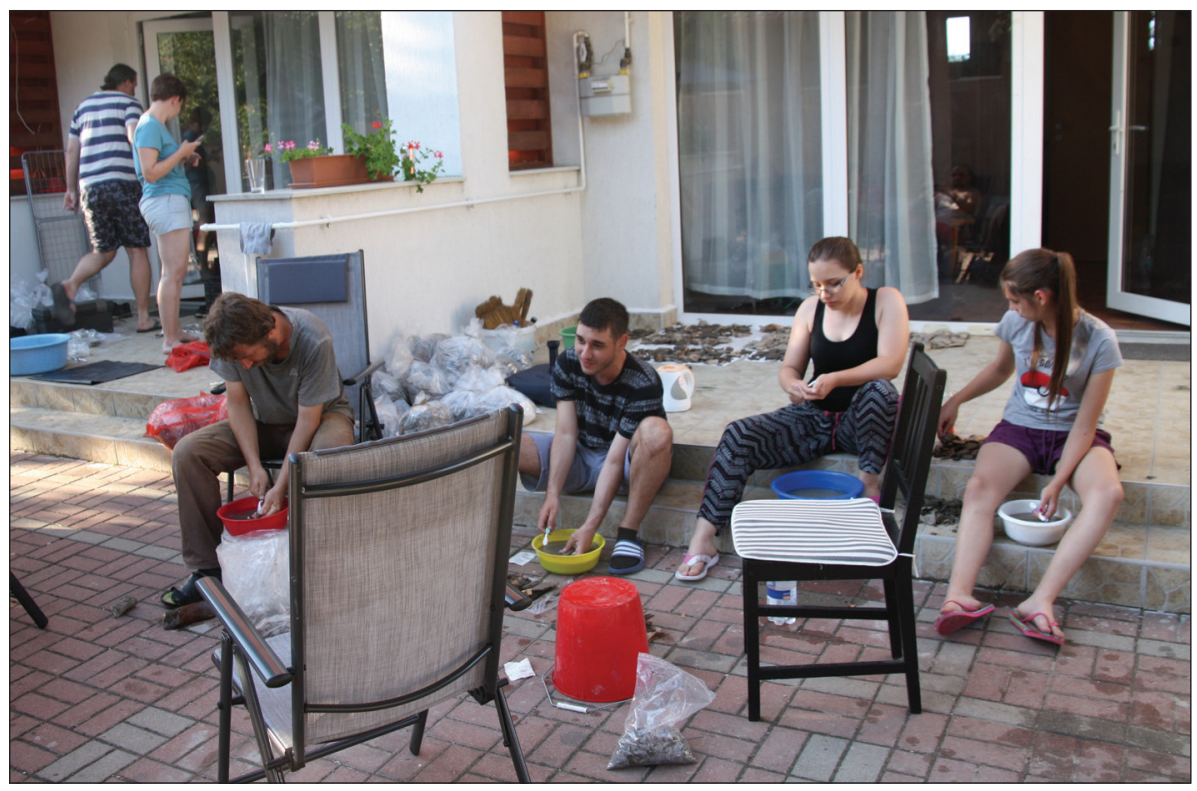

Fig. 15. Cleaning the finds at the end of the day at the basecamp in Cserkeszőlö. 


\section{References}

DomboróczKi, L. - RACZKy, P. 2010: Excavations at Ibrány and the northernmost distribution of the Körös culture. In: KozŁowski, J. K.-Raczky, P. (eds): Neolithization of the Carpathian Basin: northernmost distribution of the Starčevo/Körös Culture. Papers presented on the symposium organized by the EU project FEPRE. Kraków, 191-218.

Duffy, P. R. - Parkinson, W. A. - Gyucha, A. - Yerkes, R. W. 2013: Coming Together, Falling Apart: A Multiscalar Approach to Prehistoric Aggregation and Interaction on the Great Hungarian Plain. In: Birch, J. (ed.): From Prehistoric Villages to Cities: Settlement Aggregation and Community Transformation. New York, 44-62.

FÜZESI, A. - RAczky, P. 2018: Öcsöd-Kováshalom. Potscape of a Late Neolithic site in the Tisza Region. Dissertationes Archaeologicae 3/6, 43-146.

FÜZesi, A. - RAssmann, K. - BÁNfFy, E. - RAczky, P. 2020: Human Activities on a Late Neolithic Tell-like Settlement Complex of the Hungarian Plain (Öcsöd-Kováshalom). In: BlAnco-GonzÁlez, A.Kienlin, T. L. (eds): Current Approaches to Tells in the Prehistoric Old World. OxfordPhiladelphia, 139-161.

Gyucha, A. - PArkinson, W. A. 2008: A Körös-vidék településrendszerének változásai a Kr. e. 5. évezredben. In: BóKA, G.-MARTYin, E. (eds): Körös-menti évezredek. Régészeti ökológiai és településtörténeti kutatások a Körös-vidéken. Gyulai Katalógusok 13. Gyula, 65-106.

Hertelendi, E. - Horváth, F. 1992: Radiocarbon chronology of late Neolithic settlements in the Tisza-Maros region, Hungary. In: LonG, A.-KRA, R. S. (eds): Proceedings of the $14^{\text {th }}$ International ${ }^{14} \mathrm{C}$ Conference. Radiocarbon 34, 859-866. doi: 10.1017/S0033822200064171

Hertelendi, E. - Kalicz, N. - Raczky, P. - Horváth, F. - Veres, M. - Svingor, É. - Futó, I. - BarTosiewicz, L. 1995: Re-evaluation of the Neolithic in eastern Hungary based on calibrated radiocarbon dates. Radiocarbon 37, 239-244. doi: 10.1017/S0033822200030691

Hertelendi, E. - Svingor, É. - Raczky, P. - Horváth, F. - Futó, I. - Bartosiewicz, L. 1998: Duration of Tell Settlements at Four Prehistoric Sites in Hungary. In: Mook, W. G. - van DER Plicht, J. (eds.): Proceedings of the 16th International Conference. Radiocarbon 40, 659-665. doi: 10.1017/ S0033822200018592

Hofmann, R. - Medović, A. - Furholt, M. - Medović, I. - Stanković-Pešterac, T. - Dreibrodt, S. Martini, S. - Hofmann, A. 2019: Late Neolithic multicomponent sites of the Tisza region and the emergence of centripetal settlement layouts. Praehistorische Zeitschrift 94, 351-378. doi: 10.1515/pz-2019-0003

Kalicz, N. - Raczky, P. 1987: The Late Neolithic of the Tisza Region. A Survey of Recent Archaeological Research. In: TÁLAs, L.-RAczky, P. (eds): The Late Neolithic of the Tisza Region. BudapestSzolnok, 11-30.

Kalicz, N. 1989: Chronologische und terminologische Probleme im Spätneolithikum des Theißgebietes. In: BöкӧNYI, S. (ed.): Neolithic of Southeastern Europa and its Near Eastern Connections. Varia Archaeologica Hungarica 2. Budapest, 103-122.

Lefranc, Ph. - Denaire, A. - Arbogast, R.-M. 2017: Feasts and sacrifices: Fifth millennium 'pseudo-ditch' causewayed enclosures from the southern Upper Rhine valley. In: BICKLE, P.-CUMmings, V.-Hofmann, D.-Pollard, J. (eds): The Neolithic of Europe. Papers in Honour of Alasdair Whittle. Oxford, 159-173. doi: 10.2307/j.ctvh1dgtm.17

Lichardus, J. - Lichardus-Itten, M. 1997: Spätneolithische Funde von Čičarovce (Ostslowakei) und das obere Theißgebiet an der Schwelle zur frühen Kupferzeit. Saarbrücker Studien und Materialien zur Altertumskunde 4-5, 143-249.

MaKkaY, J. 1982: A magyarországi neolitikum kutatásának új eredményei: Az időrend és a népi azonositás kérdései. Budapest. 
Meier-Arendt, W. 1990 (ed.): Alltag und Religion. Jungsteinzeit in Ost-Ungarn. Ausgrabungen in Hódmezővásárhely-Gorzsa, Szegvár-Túzköves, Öcsöd-Kováshalom, Vésztő-Mágor, Berettyóújfalu-Herpály und Funde. Frankfurt am Main.

Parkinson, W. A. 2002: Integration, Interaction, and Tribal 'Cycling': The Transition to the Copper Age on the Great Hungarian Plain. In: Parkinson, W. A. (ed.): The Archaeology of Tribal Societies. International Monographs in Prehistory - Archaeological Series 15. Ann Arbor, 391-437. doi: $10.2307 /$ j.ctv8bt29z.22

Parkinson, W. A. 2006: The Social Organization of Early Copper Age Tribes on the Great Hungarian Plain. British Archaeological Reports - International Series 1573, Oxford. doi: 10.30861/9781841717883

PAvÚK, J. 1994: Štúrovo. Ein Siedlungsplatz der Kultur mit Linearkeramik und der Želiezovce-Gruppe. Archaeologica Slovaca Monographiae Studia 4, Nitra.

Raczky, P. 1987: Öcsöd-Kováshalom. A settlement of the Tisza culture. In: TÁLAs, L.-RAczky, P. (eds): The Late Neolithic of the Tisza Region. A survey recent excavations and their findings: Hódmezővásárhely-Gorzsa, Szegvár-Tüzköves, Öcsöd-Kováshalom, Vésztö-Mágor, Berettyóújfalu-Herpály. Budapest-Szolnok, 61-83.

Raczky, P. 2009: Archaeological Data on Space Use at a Tell-Like Settlement of the Tisza Culture (New Results from Öcsöd-Kováshalom, Hungary). In: Draşovean, F.-Cibotaru, D. L.-Maddison, M. (eds): Ten Years After: The Neolithic of the Balkans, as Uncovered by the Last Decade of Research. Proceedings of the Conference held at the Museum of Banat on November 9th-10th, 2007. Timissoara, 101-136.

Raczky, P. 2012: Nagykörü-Tsz Gyümölcsös. In: Anders, A.-Siklósi, Zs. (eds): The First Neolithic Sites in Central/South-East European Transect. Volume III: The Körös Culture in Eastern Hungary. British British Archaeological Reports - International Series 2334. Oxford, 97-105.

Raczky, P. 2019: Cross-Scale Settlement Morphologies and Social Formations in the Neolithic of the Great Hungarian Plain. In: Gyucha, A. (ed.): Coming Together. Comparative Approaches to Population Aggregation and Early Urbanization. IEMA Proceedings 8. New York, 259-294.

RAczky, P. - FüZESI, A. 2016a: Öcsöd-Kováshalom. A retrospective look at the interpretations of a Late Neolithic site. Dissertationes Archaeologicae 3/4, 9-42.

RACZky, P. - FÜZESI, A. 2016b: A múlt szimbolikus eseményeinek rekonstrukciója. Régészeti esettanulmány Öcsöd-Kováshalom késő neolitikus településéről (The reconstruction of symbolic events from the past. The archaeological study of a Late Neolithic site at Öcsöd-Kováshalom). Tisicum A fász-Nagykum-Szolnok megyei múzeumok évkönyve 25, 25-32.

Raczky, P. - Füzesi, A. - Anders, A. 2018: Domestic and Symbolic Activities on a Tell-like Settlement at Öcsöd-Kováshalom in the Tisza Region. In: LucA, A. S. (ed.): The Image of Divinity in the Neolithic and Eneolithic. Ways of Communication. Volume of the International Symposium, Sibiu, Romania, 26th-28th October 2017. Suceava, 117-140.

Sherratt, A. G. 1983: The development of neolithic and copper age settlement in the Great Hungarian Plain. Part II.: Site Survey and settlement dynamics. Oxford fournal of Archaeology 2, 13-41. doi: 10.1111/j.1468-0092.1983.tb00093.x

Siklósi, Zs. 2013: Traces of Social Inequality during the Late Neolithic in the Eastern Carpathian Basin. Dissertationes Pannonicae IV/3, Budapest.

Whittle, A. - Anders, A. - Bentley, A. - Bickle, P. - Cramp, L. - Domboróczki, L. - Fibiger, L. Hamilton, J. - Hedges, R. - Kalicz, N. - Kovács, Zs. E. - Marton, T. - Oross, K. - Pap, I. Raczky, P. 2013: Hungary. In: Bickle, P.-Whittle, A. (eds): The first farmers of central Europe. Diversity in LBK lifeways. Oxford, 49-97. 
Test excavation of the "pseudo-ditch" system of the Late Neolithic settlement complex...

Tab. 1. Original data of the excavated assemblage.

\begin{tabular}{|c|c|c|c|c|c|c|c|c|c|c|c|c|c|c|c|c|c|c|c|c|}
\hline \multirow[b]{2}{*}{ Unit } & \multirow[b]{2}{*}{ Level } & \multirow[b]{2}{*}{ Feature } & \multicolumn{2}{|c|}{ Pottery } & \multicolumn{2}{|c|}{ Daub } & \multicolumn{2}{|c|}{$\begin{array}{l}\text { Animal } \\
\text { bone }\end{array}$} & \multicolumn{2}{|c|}{$\begin{array}{l}\text { Chipped } \\
\text { stone }\end{array}$} & \multicolumn{2}{|c|}{$\begin{array}{l}\text { Polished } \\
\text { stone }\end{array}$} & \multicolumn{2}{|c|}{$\begin{array}{l}\text { Quern } \\
\text { stone }\end{array}$} & \multicolumn{2}{|c|}{ Bone tool } & \multicolumn{2}{|c|}{ Mussel } & \multicolumn{2}{|c|}{ Ochre } \\
\hline & & & $N$ & $W g$ & $N$ & $W g$ & $N$ & $W g$ & $N$ & $W g$ & $N$ & $W g$ & $N$ & $W g$ & $N$ & $W g$ & $N$ & $W g$ & $N$ & $W g$ \\
\hline 1 & $1 \mathrm{~A}$ & $\mathrm{H} / \mathrm{SH}$ & 12 & 26 & 0 & 0 & 1 & 2 & 0 & 0 & 0 & 0 & 0 & 0 & 0 & 0 & 0 & 0 & 0 & 0 \\
\hline 2 & $1 \mathrm{~A}$ & $\mathrm{H} / \mathrm{SH}$ & 9 & 26 & 2 & 3 & 0 & 0 & 1 & 1 & 0 & 0 & 0 & 0 & 0 & 0 & 0 & 0 & 0 & 0 \\
\hline 3 & $1 \mathrm{~A}$ & $\mathrm{H} / \mathrm{SH}$ & 5 & 18 & 2 & 4 & 0 & 0 & 1 & 15 & 0 & 0 & 0 & 0 & 0 & 0 & 0 & 0 & 0 & 0 \\
\hline 4 & $1 \mathrm{~A}$ & $\mathrm{H} / \mathrm{SH}$ & 7 & 26 & 0 & 0 & 0 & 0 & 0 & 0 & 0 & 0 & 0 & 0 & 0 & 0 & 0 & 0 & 0 & 0 \\
\hline 5 & $1 \mathrm{~A}$ & $\mathrm{H} / \mathrm{SH}$ & 14 & 58 & 5 & 8 & 0 & 0 & 2 & 8 & 0 & 0 & 0 & 0 & 0 & 0 & 0 & 0 & 0 & 0 \\
\hline 6 & $1 \mathrm{~A}$ & $\mathrm{H} / \mathrm{SH}$ & 13 & 74 & 2 & 4 & 0 & 0 & 1 & 29 & 0 & 0 & 0 & 0 & 0 & 0 & 0 & 0 & 0 & 0 \\
\hline 7 & $1 \mathrm{~A}$ & $\mathrm{H} / \mathrm{SH}$ & 11 & 55 & 0 & 0 & 2 & 3 & 2 & 1 & 0 & 0 & 0 & 0 & 0 & 0 & 0 & 0 & 0 & 0 \\
\hline 8 & $1 \mathrm{~A}$ & $\mathrm{H} / \mathrm{SH}$ & 9 & 72 & 0 & 0 & 0 & 0 & 0 & 0 & 0 & 0 & 0 & 0 & 0 & 0 & 0 & 0 & 0 & 0 \\
\hline 9 & $1 \mathrm{~B}$ & $\mathrm{H} / \mathrm{SH}$ & 13 & 43 & 0 & 0 & 2 & 7 & 2 & 2 & 0 & 0 & 0 & 0 & 0 & 0 & 0 & 0 & 0 & 0 \\
\hline 10 & $1 \mathrm{~B}$ & $\mathrm{H} / \mathrm{SH}$ & 5 & 43 & 1 & 1 & 0 & 0 & 2 & 3 & 0 & 0 & 0 & 0 & 0 & 0 & 0 & 0 & 0 & 0 \\
\hline 11 & $1 \mathrm{~B}$ & $\mathrm{H} / \mathrm{SH}$ & 9 & 34 & 0 & 0 & 0 & 0 & 0 & 0 & 0 & 0 & 0 & 0 & 0 & 0 & 0 & 0 & 0 & 0 \\
\hline 12 & $1 \mathrm{~B}$ & $\mathrm{H} / \mathrm{SH}$ & 4 & 16 & 0 & 0 & 0 & 0 & 0 & 0 & 0 & 0 & 0 & 0 & 0 & 0 & 0 & 0 & 0 & 0 \\
\hline 13 & $1 \mathrm{~B}$ & $\mathrm{H} / \mathrm{SH}$ & 2 & 11 & 0 & 0 & 0 & 0 & 0 & 0 & 0 & 0 & 0 & 0 & 0 & 0 & 0 & 0 & 0 & 0 \\
\hline 14 & 1B & $\mathrm{H} / \mathrm{SH}$ & 2 & 4 & 0 & 0 & 0 & 0 & 0 & 0 & 0 & 0 & 0 & 0 & 0 & 0 & 0 & 0 & 0 & 0 \\
\hline 15 & $1 \mathrm{~B}$ & $\mathrm{H} / \mathrm{SH}$ & 3 & 14 & 0 & 0 & 0 & 0 & 1 & 11 & 0 & 0 & 0 & 0 & 0 & 0 & 0 & 0 & 0 & 0 \\
\hline 16 & $1 \mathrm{~B}$ & $\mathrm{H} / \mathrm{SH}$ & 4 & 7 & 0 & 0 & 0 & 0 & 0 & 0 & 0 & 0 & 0 & 0 & 0 & 0 & 0 & 0 & 0 & 0 \\
\hline 17 & $2 \mathrm{~A}$ & $\mathrm{H} / \mathrm{SH}$ & 12 & 35 & 2 & 1 & 2 & 1 & 0 & 0 & 0 & 0 & 0 & 0 & 0 & 0 & 0 & 0 & 0 & 0 \\
\hline 18 & $2 \mathrm{~A}$ & $\mathrm{H} / \mathrm{SH}$ & 23 & 78 & 3 & 4 & 0 & 0 & 2 & 1 & 0 & 0 & 0 & 0 & 0 & 0 & 0 & 0 & 0 & 0 \\
\hline 19 & $2 \mathrm{~A}$ & $\mathrm{H} / \mathrm{SH}$ & 9 & 19 & 2 & 3 & 0 & 0 & 0 & 0 & 0 & 0 & 0 & 0 & 0 & 0 & 0 & 0 & 0 & 0 \\
\hline 20 & $2 \mathrm{~A}$ & $\mathrm{H} / \mathrm{SH}$ & 17 & 70 & 4 & 7 & 0 & 0 & 0 & 0 & 0 & 0 & 0 & 0 & 0 & 0 & 0 & 0 & 0 & 0 \\
\hline 21 & $2 \mathrm{~A}$ & $\mathrm{H} / \mathrm{SH}$ & 41 & 97 & 3 & 3 & 0 & 0 & 5 & 7 & 0 & 0 & 0 & 0 & 0 & 0 & 0 & 0 & 0 & 0 \\
\hline 22 & $2 \mathrm{~A}$ & $\mathrm{H} / \mathrm{SH}$ & 25 & 75 & 2 & 11 & 2 & 2 & 0 & 0 & 0 & 0 & 0 & 0 & 0 & 0 & 0 & 0 & 0 & 0 \\
\hline 23 & $2 \mathrm{~A}$ & $\mathrm{H} / \mathrm{SH}$ & 18 & 74 & 0 & 0 & 0 & 0 & 2 & 7 & 0 & 0 & 0 & 0 & 0 & 0 & 0 & 0 & 0 & 0 \\
\hline 24 & $2 \mathrm{~A}$ & $\mathrm{H} / \mathrm{SH}$ & 19 & 71 & 4 & 2 & 1 & 1 & 1 & 1 & 0 & 0 & 0 & 0 & 0 & 0 & 0 & 0 & 0 & 0 \\
\hline 25 & $2 \mathrm{~B}$ & $\mathrm{H} / \mathrm{SH}$ & 5 & 17 & 0 & 0 & 0 & 0 & 2 & 29 & 0 & 0 & 0 & 0 & 0 & 0 & 0 & 0 & 0 & 0 \\
\hline 26 & $2 \mathrm{~B}$ & $\mathrm{H} / \mathrm{SH}$ & 2 & 10 & 0 & 0 & 0 & 0 & 0 & 0 & 0 & 0 & 0 & 0 & 0 & 0 & 0 & 0 & 0 & 0 \\
\hline 27 & $2 \mathrm{~B}$ & $\mathrm{H} / \mathrm{SH}$ & 9 & 57 & 0 & 0 & 0 & 0 & 0 & 0 & 0 & 0 & 0 & 0 & 0 & 0 & 0 & 0 & 0 & 0 \\
\hline 28 & $2 \mathrm{~B}$ & $\mathrm{H} / \mathrm{SH}$ & 7 & 21 & 0 & 0 & 0 & 0 & 1 & 1 & 0 & 0 & 0 & 0 & 0 & 0 & 0 & 0 & 0 & 0 \\
\hline 29 & $2 \mathrm{~B}$ & $\mathrm{H} / \mathrm{SH}$ & 13 & 53 & 0 & 0 & 0 & 0 & 0 & 0 & 0 & 0 & 0 & 0 & 0 & 0 & 0 & 0 & 0 & 0 \\
\hline 30 & $2 \mathrm{~B}$ & $\mathrm{H} / \mathrm{SH}$ & 13 & 64 & 0 & 0 & 0 & 0 & 1 & 1 & 0 & 0 & 0 & 0 & 0 & 0 & 0 & 0 & 0 & 0 \\
\hline 31 & $2 \mathrm{~B}$ & $\mathrm{H} / \mathrm{SH}$ & 17 & 89 & 0 & 0 & 0 & 0 & 1 & 1 & 0 & 0 & 0 & 0 & 0 & 0 & 0 & 0 & 0 & 0 \\
\hline 32 & $2 \mathrm{~B}$ & $\mathrm{H} / \mathrm{SH}$ & 4 & 38 & 0 & 0 & 0 & 0 & 0 & 0 & 0 & 0 & 0 & 0 & 0 & 0 & 0 & 0 & 0 & 0 \\
\hline 33 & $3 \mathrm{~A}$ & $\mathrm{H} / \mathrm{SH}$ & 72 & 248 & 11 & 12 & 21 & 42 & 4 & 3 & 0 & 0 & 0 & 0 & 0 & 0 & 0 & 0 & 5 & 8 \\
\hline 34 & $3 \mathrm{~A}$ & $\mathrm{H} / \mathrm{SH}$ & 90 & 318 & 14 & 16 & 27 & 80 & 0 & 0 & 0 & 0 & 0 & 0 & 0 & 0 & 0 & 0 & 0 & 0 \\
\hline 35 & $3 \mathrm{~A}$ & $\mathrm{H} / \mathrm{SH}$ & 59 & 214 & 14 & 17 & 18 & 26 & 4 & 3 & 0 & 0 & 1 & 12 & 1 & 2 & 0 & 0 & 0 & 0 \\
\hline 36 & $3 \mathrm{~A}$ & $\mathrm{H} / \mathrm{SH}$ & 40 & 133 & 8 & 7 & 12 & 53 & 5 & 25 & 0 & 0 & 0 & 0 & 0 & 0 & 0 & 0 & 0 & 0 \\
\hline 37 & $3 \mathrm{~A}$ & $\mathrm{H} / \mathrm{SH}$ & 65 & 374 & 7 & 10 & 12 & 23 & 4 & 7 & 0 & 0 & 0 & 0 & 0 & 0 & 0 & 0 & 0 & 0 \\
\hline 38 & $3 \mathrm{~A}$ & $\mathrm{H} / \mathrm{SH}$ & 67 & 431 & 7 & 27 & 11 & 40 & 3 & 7 & 0 & 0 & 0 & 0 & 0 & 0 & 0 & 0 & 1 & 2 \\
\hline 39 & $3 \mathrm{~A}$ & $\mathrm{H} / \mathrm{SH}$ & 91 & 329 & 20 & 39 & 18 & 121 & 7 & 22 & 0 & 0 & 0 & 0 & 1 & 7 & 0 & 0 & 2 & 1 \\
\hline 40 & $3 \mathrm{~A}$ & $\mathrm{H} / \mathrm{SH}$ & 98 & 340 & 25 & 30 & 34 & 137 & 14 & 18 & 0 & 0 & 0 & 0 & 0 & 0 & 0 & 0 & 5 & 6 \\
\hline 41 & $3 \mathrm{~B}$ & $\mathrm{H} / \mathrm{SH}$ & 67 & 274 & 6 & 12 & 9 & 8 & 6 & 8 & 0 & 0 & 0 & 0 & 0 & 0 & 0 & 0 & 1 & 1 \\
\hline 42 & $3 \mathrm{~B}$ & $\mathrm{H} / \mathrm{SH}$ & 41 & 164 & 1 & 2 & 10 & 29 & 2 & 7 & 0 & 0 & 0 & 0 & 0 & 0 & 0 & 0 & 1 & 4 \\
\hline 43 & $3 \mathrm{~B}$ & $\mathrm{H} / \mathrm{SH}$ & 49 & 220 & 2 & 3 & 10 & 38 & 4 & 3 & 0 & 0 & 0 & 0 & 0 & 0 & 0 & 0 & 0 & 0 \\
\hline 44 & $3 \mathrm{~B}$ & $\mathrm{H} / \mathrm{SH}$ & 45 & 233 & 1 & 2 & 8 & 32 & 12 & 69 & 0 & 0 & 1 & 25 & 0 & 0 & 0 & 0 & 0 & 0 \\
\hline 45 & $3 \mathrm{~B}$ & $\mathrm{H} / \mathrm{SH}$ & 25 & 141 & 2 & 8 & 2 & 4 & 1 & 1 & 0 & 0 & 0 & 0 & 0 & 0 & 0 & 0 & 1 & 1 \\
\hline 46 & $3 B$ & $\mathrm{H} / \mathrm{SH}$ & 78 & 369 & 4 & 10 & 13 & 38 & 4 & 8 & 0 & 0 & 0 & 0 & 0 & 0 & 0 & 0 & 0 & 0 \\
\hline
\end{tabular}


András FüZESI - Knut RASSMANN - Eszter BÁNFFy et al.

\begin{tabular}{|c|c|c|c|c|c|c|c|c|c|c|c|c|c|c|c|c|c|c|c|c|}
\hline \multirow[b]{2}{*}{ Unit } & \multirow[b]{2}{*}{ Level } & \multirow[b]{2}{*}{ Feature } & \multicolumn{2}{|c|}{ Pottery } & \multicolumn{2}{|c|}{ Daub } & \multicolumn{2}{|c|}{$\begin{array}{c}\text { Animal } \\
\text { bone }\end{array}$} & \multicolumn{2}{|c|}{$\begin{array}{c}\text { Chipped } \\
\text { stone }\end{array}$} & \multicolumn{2}{|c|}{$\begin{array}{c}\text { Polished } \\
\text { stone }\end{array}$} & \multicolumn{2}{|c|}{$\begin{array}{l}\text { Quern } \\
\text { stone }\end{array}$} & \multicolumn{2}{|c|}{ Bone tool } & \multicolumn{2}{|c|}{ Mussel } & \multicolumn{2}{|c|}{ Ochre } \\
\hline & & & $N$ & $W g$ & $N$ & $W g$ & $N$ & $W g$ & $N$ & $W g$ & $N$ & $W g$ & $N$ & $W g$ & $N$ & $W g$ & $N$ & $W g$ & $N$ & $W g$ \\
\hline 47 & $3 \mathrm{~B}$ & $\mathrm{H} / \mathrm{SH}$ & 99 & 489 & 8 & 26 & 19 & 77 & 8 & 32 & 0 & 0 & 0 & 0 & 0 & 0 & 0 & 0 & 0 & 0 \\
\hline 48 & $3 \mathrm{~B}$ & $\mathrm{H} / \mathrm{SH}$ & 95 & 497 & 13 & 16 & 17 & 30 & 11 & 48 & 0 & 0 & 0 & 0 & 0 & 0 & 0 & 0 & 0 & 0 \\
\hline 49 & $4 \mathrm{~A}$ & $\mathrm{H} / \mathrm{SH}$ & 78 & 545 & 4 & 18 & 50 & 158 & 5 & 8 & 0 & 0 & 0 & 0 & 0 & 0 & 9 & 8 & 0 & 0 \\
\hline 50 & $4 \mathrm{~A}$ & $\mathrm{H} / \mathrm{SH}$ & 70 & 681 & 3 & 24 & 39 & 252 & 3 & 10 & 0 & 0 & 0 & 0 & 0 & 0 & 1 & 4 & 1 & 3 \\
\hline 51 & $4 \mathrm{~A}$ & $\mathrm{H} / \mathrm{SH}$ & 107 & 581 & 17 & 47 & 56 & 215 & 9 & 26 & 0 & 0 & 1 & 16 & 0 & 0 & 6 & 8 & 4 & 15 \\
\hline 52 & $4 \mathrm{~A}$ & $\mathrm{H} / \mathrm{SH}$ & 125 & 637 & 32 & 45 & 37 & 91 & 13 & 60 & 0 & 0 & 0 & 0 & 0 & 0 & 8 & 4 & 1 & 1 \\
\hline 53 & $4 \mathrm{~A}$ & $\mathrm{H} / \mathrm{SH}$ & 126 & 738 & 9 & 30 & 58 & 175 & 19 & 71 & 0 & 0 & 0 & 0 & 0 & 0 & 18 & 15 & 1 & 1 \\
\hline 54 & $4 \mathrm{~A}$ & $\mathrm{H} / \mathrm{SH}$ & 105 & 1002 & 10 & 74 & 68 & 478 & 11 & 56 & 0 & 0 & 0 & 0 & 0 & 0 & 12 & 31 & 1 & 2 \\
\hline 55 & $4 \mathrm{~A}$ & $\mathrm{H} / \mathrm{SH}$ & 100 & 975 & 3 & 28 & 69 & 641 & 5 & 19 & 1 & 15 & 0 & 0 & 0 & 0 & 77 & 164 & 0 & 0 \\
\hline 56 & $4 \mathrm{~A}$ & $\mathrm{H} / \mathrm{SH}$ & 83 & 713 & 2 & 3 & 51 & 326 & 1 & 1 & 0 & 0 & 0 & 0 & 0 & 0 & 23 & 35 & 1 & 2 \\
\hline 57 & $4 \mathrm{~B}$ & $\mathrm{H} / \mathrm{SH}$ & 99 & 1026 & 5 & 8 & 35 & 92 & 5 & 5 & 0 & 0 & 0 & 0 & 0 & 0 & 10 & 11 & 0 & 0 \\
\hline 58 & $4 \mathrm{~B}$ & $\mathrm{H} / \mathrm{SH}$ & 75 & 370 & 13 & 39 & 40 & 128 & 13 & 90 & 0 & 0 & 0 & 0 & 0 & 0 & 12 & 13 & 3 & 10 \\
\hline 59 & $4 \mathrm{~B}$ & $\mathrm{H} / \mathrm{SH}$ & 90 & 622 & 14 & 48 & 38 & 162 & 14 & 77 & 0 & 0 & 0 & 0 & 0 & 0 & 5 & 8 & 5 & 18 \\
\hline 60 & $4 \mathrm{~B}$ & $\mathrm{H} / \mathrm{SH}$ & 81 & 329 & 9 & 33 & 18 & 75 & 17 & 44 & 0 & 0 & 0 & 0 & 0 & 0 & 2 & 1 & 1 & 2 \\
\hline 61 & $4 \mathrm{~B}$ & $\mathrm{H} / \mathrm{SH}$ & 67 & 630 & 7 & 25 & 40 & 186 & 7 & 72 & 0 & 0 & 1 & 54 & 0 & 0 & 6 & 13 & 0 & 0 \\
\hline 62 & $4 \mathrm{~B}$ & $\mathrm{H} / \mathrm{SH}$ & 94 & 677 & 10 & 31 & 27 & 121 & 7 & 32 & 0 & 0 & 1 & 15 & 0 & 0 & 19 & 23 & 1 & 1 \\
\hline 63 & $4 \mathrm{~B}$ & $\mathrm{H} / \mathrm{SH}$ & 80 & 866 & 6 & 16 & 48 & 250 & 3 & 17 & 0 & 0 & 0 & 0 & 0 & 0 & 12 & 13 & 1 & 7 \\
\hline 64 & $4 \mathrm{~B}$ & $\mathrm{H} / \mathrm{SH}$ & 80 & 666 & 1 & 4 & 42 & 347 & 1 & 2 & 0 & 0 & 0 & 0 & 0 & 0 & 16 & 22 & 1 & 1 \\
\hline 65 & $5 \mathrm{~A}$ & & 46 & 194 & 6 & 6 & 23 & 69 & 2 & 2 & 0 & 0 & 0 & 0 & 0 & 0 & 12 & 22 & 0 & 0 \\
\hline 66 & $5 \mathrm{~A}$ & & 49 & 646 & 5 & 33 & 39 & 544 & 4 & 13 & 0 & 0 & 0 & 0 & 0 & 0 & 5 & 8 & 1 & 19 \\
\hline 67 & $5 \mathrm{~A}$ & & 79 & 851 & 3 & 42 & 60 & 557 & 4 & 25 & 0 & 0 & 0 & 0 & 0 & 0 & 7 & 12 & 2 & 10 \\
\hline 68 & $5 \mathrm{~A}$ & $\mathrm{H} / \mathrm{SH}$ & 123 & 1479 & 2 & 19 & 140 & 2404 & 5 & 23 & 0 & 0 & 0 & 0 & 0 & 0 & 19 & 52 & 0 & 0 \\
\hline 69 & $5 \mathrm{~A}$ & $\mathrm{H} / \mathrm{SH}$ & 74 & 1179 & 4 & 31 & 109 & 1764 & 2 & 4 & 0 & 0 & 0 & 0 & 0 & 0 & 134 & 494 & 4 & 17 \\
\hline 70 & $5 \mathrm{~A}$ & $\mathrm{H} / \mathrm{SH}$ & 116 & 2180 & 3 & 39 & 77 & 1078 & 1 & 13 & 0 & 0 & 0 & 0 & 1 & 9 & 44 & 142 & 3 & 28 \\
\hline 71 & $5 \mathrm{~A}$ & $\mathrm{H} / \mathrm{SH}$ & 77 & 2392 & 9 & 62 & 32 & 484 & 3 & 15 & 1 & 83 & 2 & 33 & 1 & 95 & 115 & 369 & 6 & 75 \\
\hline 72 & $5 \mathrm{~A}$ & $\mathrm{H} / \mathrm{SH}$ & 79 & 1693 & 2 & 22 & 30 & 336 & 2 & 63 & 0 & 0 & 0 & 0 & 1 & 17 & 24 & 73 & 5 & 21 \\
\hline 73 & $5 \mathrm{~B}$ & $\mathrm{H} / \mathrm{SH}$ & 87 & 602 & 4 & 5 & 21 & 48 & 3 & 4 & 0 & 0 & 0 & 0 & 0 & 0 & 10 & 19 & 5 & 10 \\
\hline 74 & $5 B$ & $\mathrm{H} / \mathrm{SH}$ & 48 & 452 & 0 & 0 & 7 & 42 & 2 & 62 & 0 & 0 & 0 & 0 & 2 & 8 & 12 & 18 & 2 & 7 \\
\hline 75 & $5 B$ & $\mathrm{H} / \mathrm{SH}$ & 87 & 995 & 1 & 3 & 22 & 186 & 4 & 61 & 0 & 0 & 0 & 0 & 0 & 0 & 14 & 34 & 0 & 0 \\
\hline 76 & $5 \mathrm{~B}$ & $\mathrm{H} / \mathrm{SH}$ & 98 & 1469 & 11 & 34 & 26 & 345 & 1 & 21 & 0 & 0 & 0 & 0 & 1 & 2 & 15 & 36 & 2 & 21 \\
\hline 77 & $5 \mathrm{~B}$ & $\mathrm{H} / \mathrm{SH}$ & 41 & 642 & 9 & 44 & 45 & 505 & 4 & 78 & 0 & 0 & 0 & 0 & 0 & 0 & 10 & 30 & 0 & 0 \\
\hline 78 & 5B & $\mathrm{H} / \mathrm{SH}$ & 79 & 2216 & 8 & 32 & 60 & 777 & 4 & 22 & 0 & O & 0 & 0 & 0 & 0 & 10 & 33 & 1 & 8 \\
\hline 79 & 5B & $\mathrm{H} / \mathrm{SH}$ & 58 & 1396 & 1 & 5 & 19 & 84 & 2 & 8 & 0 & 0 & 0 & 0 & 0 & 0 & 6 & 11 & 1 & 2 \\
\hline 80 & $5 \mathrm{~B}$ & $\mathrm{H} / \mathrm{SH}$ & 65 & 733 & 4 & 8 & 13 & 112 & 1 & 1 & 0 & 0 & D & 0 & 1 & 11 & 7 & 17 & 2 & 11 \\
\hline 81 & $6 \mathrm{~A}$ & $\mathrm{H} / \mathrm{SH}$ & 4 & 14 & 0 & 0 & 4 & 27 & 0 & 0 & 0 & 0 & 0 & 0 & 1 & 2 & 1 & 4 & 0 & 0 \\
\hline 82 & $6 \mathrm{~A}$ & DUW & 99 & 1078 & 7 & 24 & 17 & 50 & 8 & 112 & 1 & 57 & 1 & 337 & 0 & 0 & 13 & 16 & 0 & 0 \\
\hline 83 & $6 \mathrm{~A}$ & DUW & 113 & 1130 & 2 & 3 & 65 & 490 & 9 & 44 & 0 & 0 & 0 & 0 & 0 & 0 & 29 & 52 & 2 & 11 \\
\hline 84 & $6 \mathrm{~A}$ & DUW & 99 & 1064 & 0 & 0 & 73 & 1324 & 3 & 5 & 0 & 0 & 0 & 0 & 2 & 129 & 15 & 37 & 3 & 6 \\
\hline 85 & $6 \mathrm{~A}$ & DUW & 156 & 2485 & 7 & 29 & 172 & 4677 & 5 & 39 & 0 & 0 & 0 & 0 & 1 & 2 & 40 & 112 & 3 & 32 \\
\hline 86 & $6 \mathrm{~A}$ & DUE & 103 & 1382 & 0 & 0 & 65 & 602 & 1 & 4 & 0 & 0 & 0 & 0 & 1 & 3 & 35 & 85 & 2 & 4 \\
\hline 87 & $6 \mathrm{~A}$ & DUE & 98 & 1265 & 5 & 35 & 30 & 396 & 1 & 3 & 0 & 0 & 0 & 0 & 0 & 0 & 17 & 58 & 1 & 5 \\
\hline 88 & $6 \mathrm{~A}$ & $\mathrm{PitU}$ & 42 & 610 & 9 & 63 & 13 & 182 & 2 & 2 & 0 & 0 & 0 & 0 & 0 & 0 & 9 & 13 & 0 & 0 \\
\hline 89 & $6 \mathrm{~B}$ & $\mathrm{H} / \mathrm{SH}$ & 11 & 93 & 0 & 0 & 1 & 1 & 0 & 0 & 0 & 0 & 0 & 0 & 0 & 0 & 1 & 2 & 0 & 0 \\
\hline 90 & $6 \mathrm{~B}$ & DUW & 63 & 477 & 10 & 391 & 15 & 38 & 6 & 40 & 0 & 0 & 0 & 0 & 1 & 1 & 7 & 10 & 1 & 3 \\
\hline 91 & $6 \mathrm{~B}$ & DUW & 110 & 1362 & 10 & 87 & 30 & 653 & 6 & 47 & 0 & 0 & 0 & 0 & 1 & 1 & 15 & 40 & 3 & 24 \\
\hline 92 & $6 \mathrm{~B}$ & DUW & 133 & 1626 & 7 & 45 & 43 & 628 & 4 & 28 & 0 & 0 & 0 & 0 & 0 & 0 & 14 & 28 & 3 & 16 \\
\hline 93 & $6 \mathrm{~B}$ & DUW & 69 & 930 & 4 & 33 & 32 & 297 & 4 & 56 & 0 & 0 & 0 & 0 & 0 & 0 & 12 & 49 & 3 & 7 \\
\hline 94 & $6 \mathrm{~B}$ & DUE & 88 & 1558 & 8 & 25 & 46 & 536 & 2 & 16 & 0 & 0 & 0 & 0 & 0 & 0 & 23 & 55 & 8 & 73 \\
\hline
\end{tabular}


Test excavation of the "pseudo-ditch" system of the Late Neolithic settlement complex...

\begin{tabular}{|c|c|c|c|c|c|c|c|c|c|c|c|c|c|c|c|c|c|c|c|c|}
\hline \multirow[b]{2}{*}{ Unit } & \multirow[b]{2}{*}{ Level } & \multirow[b]{2}{*}{ Feature } & \multicolumn{2}{|c|}{ Pottery } & \multicolumn{2}{|c|}{ Daub } & \multicolumn{2}{|c|}{$\begin{array}{l}\text { Animal } \\
\text { bone }\end{array}$} & \multicolumn{2}{|c|}{$\begin{array}{l}\text { Chipped } \\
\text { stone }\end{array}$} & \multicolumn{2}{|c|}{$\begin{array}{l}\text { Polished } \\
\text { stone }\end{array}$} & \multicolumn{2}{|c|}{$\begin{array}{l}\text { Quern } \\
\text { stone }\end{array}$} & \multicolumn{2}{|c|}{ Bone tool } & \multicolumn{2}{|c|}{ Mussel } & \multicolumn{2}{|c|}{ Ochre } \\
\hline & & & $N$ & $W g$ & $N$ & $W g$ & $N$ & $W g$ & $N$ & $W g$ & $N$ & $W g$ & $N$ & $W g$ & $N$ & $W g$ & $N$ & $W g$ & $N$ & $W g$ \\
\hline 95 & $6 \mathrm{~B}$ & DUE & 78 & 1549 & 12 & 70 & 34 & 281 & 1 & 4 & 0 & 0 & 0 & 0 & 0 & 0 & 16 & 35 & 2 & 8 \\
\hline 96 & $6 \mathrm{~B}$ & PitU & 99 & 2569 & 35 & 641 & 23 & 536 & 0 & 0 & 0 & 0 & 0 & 0 & 0 & 0 & 8 & 8 & 4 & 34 \\
\hline 98 & 7A & DUW & 88 & 797 & 12 & 179 & 11 & 30 & 6 & 17 & 0 & 0 & 0 & 0 & 0 & 0 & 11 & 22 & 1 & 8 \\
\hline 99 & 7A & DUW & 154 & 2330 & 10 & 100 & 56 & 404 & 11 & 92 & 0 & 0 & 0 & 0 & 0 & 0 & 26 & 86 & 1 & 2 \\
\hline 100 & 7A & DUW & 171 & 2657 & 12 & 112 & 127 & 1644 & 12 & 46 & 0 & 0 & 1 & 152 & 1 & 52 & 39 & 72 & 1 & 4 \\
\hline 101 & 7A & DUW & 137 & 2069 & 8 & 37 & 78 & 972 & 2 & 60 & 0 & 0 & 0 & 0 & 0 & 0 & 24 & 62 & 0 & 0 \\
\hline 102 & 7A & DUE & 130 & 2443 & 10 & 513 & 66 & 1240 & 2 & 14 & 0 & 0 & 0 & 0 & 0 & 0 & 35 & 103 & 9 & 87 \\
\hline 103 & $7 \mathrm{~A}$ & DUE & 155 & 3476 & 13 & 418 & 68 & 1380 & 8 & 167 & 1 & 41 & 0 & 0 & 1 & 8 & 55 & 96 & 4 & 7 \\
\hline 104 & 7A & PitU & 49 & 715 & 0 & 0 & 38 & 428 & 1 & 2 & 0 & 0 & 0 & 0 & 0 & 0 & 5 & 20 & 0 & 0 \\
\hline 106 & 7B & DUW & 61 & 1186 & 32 & 3155 & 9 & 53 & 7 & 22 & 1 & 32 & 0 & 0 & 0 & 0 & 7 & 17 & 1 & 1 \\
\hline 107 & 7B & DUW & 155 & 1588 & 14 & 83 & 57 & 475 & 12 & 47 & 0 & 0 & 0 & 0 & 2 & 21 & 31 & 41 & 5 & 20 \\
\hline 108 & 7B & DUW & 130 & 1548 & 4 & 32 & 60 & 655 & 12 & 115 & 0 & 0 & 0 & 0 & 0 & 0 & 19 & 34 & 2 & 16 \\
\hline 109 & $7 \mathrm{~B}$ & DUW & 136 & 1711 & 21 & 251 & 76 & 1102 & 7 & 89 & 0 & 0 & 0 & 0 & 0 & 0 & 27 & 78 & 2 & 7 \\
\hline 110 & 7B & DUE & 147 & 2523 & 24 & 906 & 64 & 899 & 1 & 3 & 0 & 0 & 0 & 0 & 0 & 0 & 35 & 99 & 1 & 1 \\
\hline 111 & $7 \mathrm{~B}$ & DUE & 118 & 1849 & 34 & 365 & 55 & 749 & 4 & 4 & 0 & 0 & 0 & 0 & 0 & 0 & 20 & 54 & 4 & 5 \\
\hline 112 & 7B & PitU & 65 & 965 & 27 & 343 & 53 & 768 & 2 & 4 & 0 & 0 & 0 & 0 & 0 & 0 & 4 & 6 & 3 & 9 \\
\hline 114 & 8 & DUW & 48 & 587 & 20 & 2034 & 13 & 46 & 4 & 38 & 0 & 0 & 0 & 0 & 0 & 0 & 8 & 16 & 0 & 0 \\
\hline 115 & 8 & DUW & 133 & 1496 & 5 & 105 & 47 & 336 & 4 & 26 & 1 & 2 & 0 & 0 & 1 & 2 & 18 & 50 & 2 & 11 \\
\hline 116 & 8 & DUW & 300 & 3998 & 30 & 348 & 84 & 827 & 17 & 104 & 0 & 0 & 0 & 0 & 1 & 2 & 46 & 111 & 3 & 4 \\
\hline 117 & 8 & DUE & 230 & 3792 & 9 & 301 & 170 & 2272 & 11 & 24 & 0 & 0 & 0 & 0 & 2 & 64 & 42 & 100 & 2 & 12 \\
\hline 118 & 8 & DUE & 147 & 1620 & 14 & 870 & 58 & 529 & 11 & 67 & 0 & 0 & 0 & 0 & 0 & 0 & 53 & 74 & 8 & 17 \\
\hline 119 & 8 & DUE & 90 & 1397 & 16 & 242 & 31 & 440 & 4 & 15 & 0 & 0 & 0 & 0 & 1 & 2 & 51 & 68 & 3 & 3 \\
\hline 120 & 8 & PitU & 116 & 1342 & 12 & 114 & 81 & 916 & 7 & 55 & 0 & 0 & 0 & 0 & 0 & 0 & 17 & 21 & 4 & 14 \\
\hline 121 & 9 & DUW & 16 & 236 & 2 & 7 & 6 & 29 & 0 & 0 & 1 & 4 & 0 & 0 & 0 & 0 & 5 & 4 & 0 & 0 \\
\hline 122 & 9 & & 16 & 125 & 7 & 48 & 4 & 19 & 0 & | & 0 & 0 & 0 & 0 & 0 & 0 & 1 & 1 & 1 & 8 \\
\hline 123 & 9 & & 107 & 1240 & 12 & 248 & 20 & 94 & 7 & & 0 & 0 & 0 & 0 & 0 & 0 & 30 & 44 & 2 & 20 \\
\hline 124 & 9 & DUE & 102 & 1476 & 7 & & 92 & 1532 & 5 & 3 & 0 & 0 & 3 & 667 & 0 & 0 & 173 & 615 & 1 & 3 \\
\hline 125 & 9 & DUE & 89 & 1527 & 7 & 301 & 53 & 576 & 4 & & 0 & 0 & 0 & 0 & 0 & 0 & 57 & 109 & 1 & 1 \\
\hline 126 & 9 & DUE & 83 & 912 & 3 & 24 & 19 & 169 & 1 & 28 & 0 & 0 & 0 & 0 & 0 & 0 & 25 & 91 & 3 & 4 \\
\hline 127 & 9 & PitU & 78 & 1747 & 6 & 9 & 102 & 947 & 4 & 115 & 0 & 0 & 0 & 0 & 1 & 4 & 27 & 82 & 3 & 32 \\
\hline 128 & 10 & DLow & 18 & 145 & 0 & 0 & 8 & 75 & 0 & 0 & 0 & 0 & 0 & 0 & 0 & 0 & 10 & 15 & 0 & 0 \\
\hline 129 & 10 & DLow & 97 & 1599 & 5 & 51 & 42 & 450 & 2 & 58 & 0 & 0 & 1 & 25 & 0 & 0 & 36 & 78 & 3 & 15 \\
\hline 130 & 10 & DLow & 54 & 689 & 4 & 43 & 9 & 249 & 9 & 108 & 0 & 0 & 0 & 0 & 0 & 0 & 13 & 22 & 1 & 11 \\
\hline 131 & 10 & DLow & 70 & 755 & 1 & 10 & 36 & 239 & 10 & 70 & 0 & 0 & 0 & 0 & 0 & 0 & 16 & 35 & 1 & 10 \\
\hline 132 & 10 & PitL & 82 & 2295 & 4 & 67 & 163 & 2472 & 2 & 28 & 0 & 0 & 0 & 0 & 2 & 288 & 22 & 76 & 0 & 0 \\
\hline 133 & 11 & DLow & 0 & 0 & 0 & 0 & 0 & 0 & 0 & 0 & 0 & 0 & 0 & 0 & 0 & 0 & 0 & 0 & 0 & 0 \\
\hline 134 & 11 & DLow & 69 & 1371 & 24 & 1367 & 7 & 106 & 3 & 18 & 0 & 0 & 0 & 0 & 0 & 0 & 12 & 22 & 0 & 0 \\
\hline 135 & 11 & DLow & 46 & 713 & 1 & 17 & 3 & 4 & 1 & - & 0 & 0 & 0 & 0 & 0 & 0 & 0 & 0 & 0 & 0 \\
\hline 136 & 11 & PitL & 31 & 423 & 0 & 0 & 9 & 381 & 4 & 33 & 0 & 0 & 0 & 0 & 0 & 0 & 2 & 1 & 3 & 7 \\
\hline 137 & 11 & PitL & 23 & 709 & 3 & 104 & 52 & 1356 & 3 & 12 & 1 & 127 & 0 & 0 & 0 & 0 & 8 & 26 & 1 & 9 \\
\hline 138 & 12 & DLow & 43 & 876 & 8 & 56 & 1 & 37 & 3 & 31 & 0 & 0 & 0 & 0 & 0 & 0 & 1 & 1 & 0 & 0 \\
\hline 139 & 12 & DLow & 21 & 344 & 2 & 102 & 0 & 0 & 0 & 0 & 0 & 0 & 0 & 0 & 0 & 0 & 0 & 0 & 0 & 0 \\
\hline 140 & 12 & PitL & 3 & 36 & 0 & 0 & 1 & 146 & 0 & 0 & 0 & 0 & 0 & 0 & 0 & 0 & 1 & 3 & 0 & 0 \\
\hline 141 & 12 & PitL & 16 & 202 & 2 & 51 & 6 & 63 & 0 & 0 & 0 & 0 & 0 & 0 & 0 & 0 & 3 & 8 & 20 & 186 \\
\hline 142 & 13 & DLow & 0 & 0 & 0 & 0 & 0 & 0 & 0 & 0 & 0 & 0 & 0 & 0 & 0 & 0 & 0 & 0 & 0 & 0 \\
\hline 143 & 13 & DLow & 0 & 0 & 0 & 0 & 0 & 0 & 0 & 0 & 0 & 0 & 0 & 0 & 0 & 0 & 0 & 0 & 0 & 0 \\
\hline 144 & 13 & PitL & 26 & 519 & 2 & 110 & 9 & 898 & 1 & 8 & 0 & 0 & 0 & 0 & 0 & 0 & 0 & 0 & 0 & 0 \\
\hline 145 & 14 & DLow & 5 & 43 & 0 & 0 & 0 & 0 & 0 & 0 & 0 & 0 & 0 & 0 & 0 & 0 & 0 & 0 & 0 & 0 \\
\hline
\end{tabular}


András FÜZEsI - Knut RAsSMANn - Eszter BÁNFFy et al.

\begin{tabular}{|c|c|c|c|c|c|c|c|c|c|c|c|c|c|c|c|c|c|c|c|c|}
\hline \multirow[b]{2}{*}{ Unit } & \multirow[b]{2}{*}{ Level } & \multirow[b]{2}{*}{ Feature } & \multicolumn{2}{|c|}{ Pottery } & \multicolumn{2}{|c|}{ Daub } & \multicolumn{2}{|c|}{$\begin{array}{c}\text { Animal } \\
\text { bone }\end{array}$} & \multicolumn{2}{|c|}{$\begin{array}{l}\text { Chipped } \\
\text { stone }\end{array}$} & \multicolumn{2}{|c|}{$\begin{array}{c}\text { Polished } \\
\text { stone }\end{array}$} & \multicolumn{2}{|c|}{$\begin{array}{l}\text { Quern } \\
\text { stone }\end{array}$} & \multicolumn{2}{|c|}{$\begin{array}{c}\text { Bone } \\
\text { tool }\end{array}$} & \multicolumn{2}{|c|}{ Mussel } & \multicolumn{2}{|c|}{ Ochre } \\
\hline & & & $N$ & $W g$ & $N$ & $W g$ & $N$ & $W g$ & $N$ & $W g$ & $N$ & $W g$ & $N$ & $W g$ & $N$ & $W g$ & $N$ & $W g$ & $N$ & $W g$ \\
\hline 146 & 14 & DLow & 3 & 42 & 1 & 3 & 2 & 10 & 0 & 0 & 0 & 0 & 0 & 0 & 0 & 0 & 3 & 7 & 0 & 0 \\
\hline 147 & 14 & PitL & 11 & 164 & 0 & 0 & 4 & 13 & 0 & 0 & 0 & 0 & 0 & 0 & 0 & 0 & 4 & 19 & 7 & 34 \\
\hline 148 & 15 & DLow & 14 & 166 & 0 & 0 & 5 & 123 & 0 & 0 & 0 & 0 & 0 & 0 & 0 & 0 & 1 & 2 & 0 & 0 \\
\hline 149 & 15 & DLow & 14 & 296 & 0 & 0 & 1 & 0 & 0 & 0 & 0 & 0 & 0 & 0 & 0 & 0 & 0 & 0 & 0 & 0 \\
\hline 150 & 15 & PitL & 20 & 470 & 2 & 37 & 4 & 101 & 2 & 70 & 0 & 0 & 1 & 20 & 0 & 0 & 2 & 15 & 0 & 0 \\
\hline
\end{tabular}

